\title{
EL PLURALISMO EN EL ORDENAMIENTO CONSTITUCIONAL ESPAÑOL
}

\author{
POR \\ PABLO NUEVO \\ Profesor de Derecho Constitucional. \\ Universidad Abat Oliva-CEU. Barcelona
}




\section{SUMARIO}

I. Introducción. II. El pluRalismo politico en el orden constitucional. III. PluRAlismo Y dignidad de LA PERSONA. IV. CONCLUSIONES. 


\section{EL PLURALISMO EN EL ORDENAMIENTO CONSTITUCIONAL ESPAÑOL}

POR

\section{PABLO NUEVO}

Profesor de Derecho Constitucional. Universidad Abat Oliva-CEU. Barcelona.

\section{INTRODUCCIÓN.}

El objeto de estas líneas es analizar cómo influye en el Estado constitucional el pluralismo político como valor superior del ordenamiento (art. 1.1 $\mathrm{CE}$ ), realizando un estudio sobre el pluralismo $y$ el bien común en el Derecho constitucional. A mi entender, está justificado abordar el estudio de este tema desde el Derecho constitucional y no sólo desde la perspectiva de la filosofía política o jurídica, por cuanto es en la Constitución como, norma jurídica fundamental y fundamentadora del ordenamiento donde puede encontrarse el problema de la tensión entre la unidad de la voluntad estatal y las consecuencias del pluralismo político.

Ernesto Benda señala que la tarea esencial de cualquier política consiste en conciliar cuanto sea posible libertad individual y bien común, precisando -en el contexto de la República Federal Alemana- que " $/ a$ Ley Fundamental intenta equilibrar las tensiones entre individuo y res publica, por un lado mediante la garantía de los derechos fundamentales; por otro, estableciendo límites y obligaciones sociales"'.

${ }^{1}$ E. BENDA. Dignidad humana y derechos de la personalidad, en el volumen colec- 
Esta afirmación de Benda pone de manifiesto uno de los temas centrales de la ciencia jurídico-política, como es la armonización de la pluralidad existente en toda comunidad política. Dicha armonización debe reconducir a una cierta unidad la pluralidad, evitando la anarquía y descomposición social que se derivan de la mera afirmación de dicha pluralidad, y evitando que el intento de llevar a la unidad a las personas y grupos sociales los absorba y aniquile la individualidad, degenerando la vida social en totalitarismo (lo cual negaría la convivencia democrática que, según se desprende del preámbulo, pretende garantizar la Constitución).

Ahora bien, ¿cómo sucede esto en el constitucionalismo contemporáneo? Miguel Ayuso ${ }^{2}$ ha resumido las características del constitucionalismo como expresión de una ideología jurídico-política que excede la mera técnica de las leyes fundamentales de la comunidad política: Constitución como norma jurídica que reconoce los derechos fundamentales y conforma toda la vida social (no sólo la organización política, sino la totalidad de las relaciones sociales; un ejemplo de este fenómeno puede encontrarse en la constitucionalización del derecho civil o en la eficacia frente a terceros de los derechos fundamentales), en el marco de un proceso de secularización de la vida social y política ${ }^{3}$.

En la ideología propia del constitucionalismo contemporáneo, además, la Constitución no sólo es norma jurídica en sentido formal, sino también en sentido material, al positivizar un sistema de valores.

En su conocido trabajo La constitución como norma y el Tribunal Constitucional, y a propósito de esta evolución del constitucionalismo, García de Enterría señala que «la Constitución es un instrumento ético al servicio de los valores sustantivos $)^{4}$, lo cual no es óbice para la significación inequívocamente jurídica de este sistema material de valores ${ }^{5}$.

tivo Manual de Derecho Constitucional, Benda, MAIHOFER, Vogel, Hesse y HeYde, $2 .^{\circ}$ edición, Marcial Pons, Madrid, 2001, p. 119.

${ }^{2} \mathrm{M}$. Aruso. El ágora y la pirámide. Una visión problemática de la Constitución española. Ed. Criterio, Madrid, 2000, p. 47 a 59.

${ }^{3}$ El propio Tribunal Constitucional, con ocasión de su pronunciamiento en relación con la promesa o juramento constitucional de los diputados de HB, ha puesto de manifiesto, bien que dentro de un razonamiento tangencial a la cuestión debatida, esta relación entre constitucionalismo contemporáneo y secularización del poder, STC 119/1990, de 21 de junio.

${ }^{4}$ E. García de Enterría. La Constitución como norma y el Tribunal Constitucional. Ed. Civitas, Madrid, 1982, p. 47.

5 Ibid., p. 100. 
Por lo que se refiere a estos valores sustantivos (entrando con ello en la cuestión del pluralismo político), y dado que el Estado debe ser "neutro» en lo que se refiere a valoraciones morales, lo sustancial de los mismos sería definir un espacio abierto que haga posible el juego de las posibles alternativas, de tal manera que "lo esencial de la Constitución no sería una cierta concepción del hombre, sino construir la vida social y política como un proceso indefinidamente abierto" ${ }^{6}$, lo que nos lleva a una primacía del pluralismo y la democracia entre todos los valores constitucionales.

Ahora bien, esta afirmación del pluralismo como admisión de visiones enfrentadas de lo que es el hombre $y$ la vida social plantea algunas cuestiones problemáticas a la misma vida comunitaria. $Y$ es que, como pone de manifiesto Conrado Hesse refiriéndose a la función de integración de la Constitución, "rallí donde, partiendo de la pluralidad de voluntades, ya no es posible formar una voluntad conjunta vinculante quiebra el Estado como unidad política de acción", señalando, respecto de la Ley Fundamental de Bonn, que "la tarea fundamental de la integración la cumple la Constitución mediante sus derechos fundamentales»?.

¿Cuál es el estado de la cuestión en nuestro ordenamiento jurídicoconstitucional? Parejo Alfonso ${ }^{8}$ sostiene que el sistema de valores de nuestro ordenamiento jurídico-constitucional son los enunciados en el art. 1.1 CE y la dignidad de la persona (que tiene derecho al libre desarrollo de su personalidad), los cuales son además los conceptos clave de la Constitución, siendo los derechos fundamentales formas de realizar esos valores y dignidad.

Pues bien, este es el núcleo de las presentes líneas, pues de la caracterización del pluralismo que logremos deducir de nuestro sistema jurídico-constitucional dependerá cómo hayan de entenderse los derechos fundamentales y la misma vida comunitaria. En este sentido, considerar el pluralismo como un pluralismo axiológico absoluto vuelve a llevar la primacía de la Constitución al campo formal (dado que el campo material sería la falta de límites de las decisiones formales, esto es, el proceso abierto y público de discusión democrática), con el riesgo de que se produzca un debilitamiento de los derechos fundamentales.

6 Ibid., p. 101.

7 C. HESSE. Constitución y Derecho constitucional, Manual de Derecho Constitucional, p. 3.

${ }^{8}$ L. Parejo Alfonso. Constitución y valores del ordenamiento. Centro de Estudios Ramón Areces, Madrid, 1990, p. 117 a 149. 


\section{EL PLURALISMO POLÍTICO EN EL ORDEN CONSTITUCIONAL.}

\section{a) Pluralidad de pluralismos en la Constitución española.}

La Constitución, en su art. 1.1, propugna el pluralismo político como uno de los valores superiores del ordenamiento. A su vez, en el art. 6 señala que "los partidos políticos expresan el pluralismo político", siendo "instrumento fundamental para la participación política». En consecuencia, parecería que en el orden constitucional el valor pluralismo - vinculado a la cláusula de Estado democrático - implicaria simplemente la necesidad de que la voluntad estatal ( $y$ la determinación de los representantes de la Nación que expresan dicha voluntad) sea formada a partir del resultado de elecciones democráticas. Esta primera interpretación se vería reforzada por el adjetivo de "político" que acompaña al pluralismo en el art. 1.1 CE.

En este sentido, el Tribunal Constitucional ha señalado que la Constitución es un marco lo suficientemente amplio en el que caben las distintas opciones políticas, correspondiendo al propioTribunal mediante la interpretación constitucional el fijar los límites dentro de los cuales pueden plantearse legítimamente dichas opciones políticas (STC 4/1981, de 2 de febrero).

No obstante esta primera aproximación, a nuestro entender el pluralismo tiene un sentido mucho más amplio en nuestra Norma fundamental.

Así, como consecuencia de una de las mayores transformaciones que ha realizado la Constitución en la articulación del Estado, podemos apreciar un pluralismo institucional y jurídico, con proyecciones lingüísticas y simbólicas. Consecuencia lógica del reconocimiento por parte del art. 2 CE de la autonomía de las nacionalidades y regiones "para la gestión de sus respectivos intereses" (art. $137 \mathrm{CE}$ ) es la existencia de una pluralidad de entes políticos de base territorial distintos del Estado (las Comunidades Autónomas), con su propio sistema institucional y su propio ordenamiento jurídico integrado en el sistema jurídico global-estatal. Nacionalidades y regiones institucionalizadas en Comunidades Autónomas con su propia lengua oficial (cooficial junto con el castellano), sus símbolos, etc ${ }^{9}$.

Profundizando en esta vertiente del pluralismo, gran parte de la doctrina considera que el significado del mismo en la Constitución es mucho mayor. Así, Lucas Verdú ${ }^{10}$ distingue cuatro vertientes del pluralismo, valor que verifica la libertad $y$ atempera la igualdad:

${ }^{9}$ Cfr. E. García de Enterria. Estudios sobre autonomías territoriales. Ed. Civitas, Madrid, 1984. También J. A. SANTAMARIA PASTOR, Fundamentos de Derecho Administrativo, Ed. CEURA, Madrid, 1992.

10 P. Lucas Verdú. Comentario al art. 1. En Óscar Alzaga (dir.), Comentario a las Leyes Políticas, EDERSA, Madrid, 1983, p. 65 y ss. 
- Vertiente autonómica, en el art. 2 CE: «La Constitución (...) reconoce y garantiza el derecho a la autonomía de las nacionalidades $y$ regiones (...)».

- Vertiente lingüística, en los apartados 2 («Las demás lenguas españolas...") y 3 ("La riqueza de las modalidades lingüísticas de España...") del art. 3 CE.

- Vertiente simbólica, en el apartado 2 del art. 4 CE: "Los Estatutos podrán reconocer banderas $y$ enseñas propias de las Comunidades Autónomas (...)").

- Vertiente político-social, en los artículos 6 (partidos políticos) y 7 (sindicatos de trabajadores y asociaciones empresariales).

Por su parte, Puy Muñoz ${ }^{11}$ entiende que el pluralismo consagrado por la Constitución es total, es decir, que además de político en sentido estricto es pluralismo social, lingüístico, moral, valorativo, simbólico, jurídico, técnico, organizativo, institucional, asociativo, religioso y cultural. Dentro de esta caracterización del pluralismo en la Constitución podemos distinguir aquellas manifestaciones que vienen exigidas por la naturaleza de las cosas (pluralismos "forzosos", como la pluralidad de municipios) y manifestaciones del pluralismo que traen causa de una elección del Constituyente (como el pluralismo religioso, el territorial, etc.).

Sin negar la existencia de estas manifestaciones o vertientes del pluralismo, el Tribunal Constitucional ${ }^{12}$ ha empleado el valor pluralismo en cuatro campos.

En primer lugar, a la hora de dotar de capacidad de acción al legislador, también en materia de derechos fundamentales, y como reverso de la garantía del contenido esencial. Precisamente por ser la Constitución un marco amplio de acción dentro del cual son admisibles determinaciones: distintas en función de las plurales y legítimas opciones políticas, a la hora de desarrollar legislativamente lo previsto en la Constitución, estas opciones políticas gozan de libertad para legislar en el sentido que consideren más oportuno, con el único límite del respeto a la Norma fundamental y a: las reglas de juego democráticas ${ }^{13}$.

11 F. PuY MuÑoz. El pluralismo en la Constitución de 1978 y el art. 1.1. En Jornadas de Estudio sobre el Título Preliminar de la Constitución, vol. l, p. 367 y ss.

12 Cfr. J.J. Santamaría IBEAS. Los valores superiores en la Jurisprudencia del Tribunal Constitucional. Dykinson, Madrid, 1997.

${ }^{13} \mathrm{Cfr}$., a modo de ejemplo, la Sentencia del Tribunal Constitucional 4/1981, de 2 de febrero. También, vid. la STC 6/1984, en cuyo fundamento jurídico 5 estableció el 
En segundo lugar, el Tribunal ha empleado el pluralismo para perfilar una técnica jurisdiccional objetiva para solucionar problemas relativos a la composición de órganos colegiados, en el sentido de que deben reflejar la pluralidad existente en la sociedad o -en el caso de órganos colegiados de gobierno de una institución parlamentaria, estatal o autonómica - en la propia cámara ${ }^{14}$.

En tercer lugar, el pluralismo ha sido en la Jurisprudencia del Tribunal Constitucional un concepto clave para determinar el papel de los partidos en una sociedad democrática. De la mano del art. $6 \mathrm{CE}$, ha destacado la importancia de los partidos en el régimen democrático, por lo que son piezas básicas del funcionamiento del Estado social y democrático de derecho ${ }^{15}$.

Finalmente, el Tribunal ha acudido al valor pluralismo poniéndolo en relación con libertades individuales, especialmente en relación con el papel de los medios de comunicación en una sociedad democrática, o para extender el alcance del derecho a la información y a la libertad de expresión ${ }^{16}$.

Tribunal que uel pluralismo político, que es uno de los valores superiores del ordenamiento (artículo 1 de la Constitución), permite contemplar en el marco de la Constitución diversas soluciones legales».

14 Cfr. STC 32/1985, de 6 de marzo. A juicio del Tribunal, wes claro, en efecto, que la inclusión del pluralismo político como un valor juridico fundamental (art. $1.1 \mathrm{CE}$ ) y la consagración constitucional de los partidos políticos como expresión de tal pluralismo, cauces para la formación y manifestación de la voluntad popular e instrumentos fundamentales para la participación política de los ciudadanos (art. 6), dotan de relevancia jurídica (y no sólo política) a la adscripción política de los representantes y que, en consecuencia, esa adscripción no puede ser ignorada, ni por las normas infraconstitucionales que regulen la estructura interna del órgano en el que tales representantes se integran, ni por el órgano mismo, en las decisiones que adopte en ejercicio de la facultad de organización que es consecuencia de su autonomía”.

15 Asi, en la STC 85/1986, de 25 de junio, el Tribunal puso de manifiesto que «la colocación sistemática de este precepto (del art. 6 CE) expresa la importancia que se reconoce a los partidos políticos dentro del sistema constitucional, y la protección que de su existencia y sus funciones se hace, no sólo desde la dimensión individual del derecho a constituirlos y a participar activamente en ellos, sino también en función de la existencia del sistema de partidos como base esencial para la actuación del pluralismo político». Cfr. también la STC 107/1991, de 13 de mayo. En esta Sentencia, y precisamente por la importancia que tienen los partidos en un régimen democrático, el Tribunal destacó que "ciertamente, no cabe negar la posibilidad, fruto del pluralismo político, de que una misma corriente ideológica pueda tener diversas expresiones políticas».

${ }^{16}$ Cfr. STC 74/1982, de 7 de diciembre, Sentencia en que el Tribunal consideró, a propósito del pluralismo y las televisiones privadas que los valores del art. 1.1 son los valores fundamentales del Estado. Asimismo, STC 12/1982, de 31 de marzo, también relativa a la cuestión de las televisiones privadas, en que el Tribunal habló del urecono- 
En relación con estos campos, elTribunal Constitucional ha razonado vinculando el pluralismo al ámbito más estrictamente político, bien sea para garantizar la representación plural de la sociedad, bien sea para garantizar la pluralidad informativa que hace posible la representación de la plural sociedad española.

Ahora bien, junto a estos campos hay otros en que -si bien el Tribunal no razona expresamente aplicando el pluralismo consagrado en el art. 1.1 CE - la cuestión del pluralismo ha afectado enormemente a la interpretación constitucional.

A título de ejemplo de cómo el pluralismo puede afectar a la interpretación constitucional, podemos hacer referencia a las consideraciones sobre la existencia o no de un modelo constitucional de familia, que, a mi entender, ilustran el efecto irradiante del pluralismo en la interpretación de la Constitución.

En la Sentencia 116/1999, de 17 de junio, el Tribunal Constitucional consideró que, precisamente por el pluralismo presente en la sociedad (valor superior del ordenamiento jurídico), la interpretación del art. $39 \mathrm{CE}$ hace que no haya un concepto constitucional de familia.

En dicha Sentencia, el Tribunal señaló lo siguiente:

"Nuestra Constitución no ha identificado la familia a la que manda proteger con la que tiene su origen en el matrimonio, ni existe ninguna construcción del concepto de familia a la de origen matrimonial, por relevante que sea en nuestra cultura -en los valores y en la realidad de los comportamientos sociales - esa modalidad de vida familiar. Existen otras junto a ella, como corresponde a una sociedad plural"

Y el Tribunal ha hecho esta interpretación a pesar de los artículos 32 y 39 , y de la cláusula interpretativa del 10.2 , esto es, aun cuando una interpretación sistemática de los artículos citados y de los textos internacionales, en los que se vincula matrimonio, familia y edad núbil -es decir, capacidad de generación-, llevan a que la CE deba proteger la familia fundada en el matrimonio, la llamada "familia tradicional»" 17 .

cimiento y la garantía de una institución política fundamental, que es la opinión pública libre, indisolublemente ligada con el pluralismo político, que es un valor fundamental $y$ un requisito del funcionamiento del Estado democrático".

17 Cfr. J.L. MARTínez LópEZ-MuÑiz. La familia en la Constitución Española. Revista Española de Derecho Constitucional, núm. 58. Enero-Abril de 2000. 
Podrá decirse que el Tribunal ha empleado, en esta Sentencia, el pluralismo de una forma tangencial; pero a nuestro entender lo relevante es esa expresión de que a la sociedad plural le corresponde una pluralidad de modelos familiares, pues es precisamente ese argumento el que inclina la interpretación del Tribunal.

Como poníamos de manifiesto más arriba, a nuestro entender, una interpretación sistemática de la Constitución y de los textos internacionales lleva a considerar que hay un concepto constitucional de familia, la fundada en el matrimonio, y que es esta familia la constitucionalmente protegida por el art. $39 \mathrm{CE}$.

En efecto, como ha señalado Martínez López-Muñiz, después de disponer en su apartado 1 que "los poderes públicos aseguran la protección social, económica y jurídica de la familian, el art. $39 \mathrm{CE}$, en su apartado 2, establece la obligación de los poderes públicos, "asimismo", de proteger a los hijos - con independencia de su filiación- y a las madres - cualquiera que sea su estado civil-. Esto es, si atendemos al sentido lógico de las expresiones constitucionales, lo que señala el art. $39 \mathrm{CE}$ es que los poderes públicos tienen que proteger a la familia, y precisamente porque la familia que tienen que proteger es la que nace con el matrimonio, señala el apartado 2 del mismo precepto que además, para evitar discriminaciones y situaciones injustas, deben proteger a los hijos que nacen fuera del matrimonio $y$ a las madres solteras. Y señala esto, como no podía ser menos, porque los hijos nacidos dentro del matrimonio y las madres cuyo estado civil es el de casadas encuentran ya amparo en la protección genérica de la familia contenida en el apartado 1 del precepto.

No sólo impone esta interpretación la redacción del precepto sino, como apuntábamos antes, los textos internacionales. De conformidad con el art. 12 del Convenio del Consejo de Europa de 1950 para la protección de los derechos humanos y de las libertades fundamentales, ratificado por España mediante Instrumento de 26 de septiembre de 1979, " $A$ partir de la edad núbil, el hombre y la mujer tienen derecho a casarse y a fundar una familia según las leyes nacionales que rijan el ejercicio de este derecho".

Igualmente, la Declaración Universal de derechos humanos y los Pactos de Nueva York de derechos civiles y políticos vinculan edad núbil (capacidad física para engendrar), matrimonio y familia, de manera que es el matrimonio el vínculo esencial fundante de la familia, y por proyección de las normas internacionales en la interpretación de los arts. 39 y $32 \mathrm{CE}$, también de la constitucionalmente protegida. 
Pues bien, a pesar de estas consideraciones, y a nuestro entender precisamente por el pluralismo, el Tribunal se ha decantado por considerar que no existe un concepto constitucional de familia.

Más allá del ejemplo concreto, lo que revela esta interpretación es que a juicio del Tribunal parece que el pluralismo carece de fundamento real, o mejor, que el pluralismo es consecuencia de la falta de fundamento real del resto de valores constitucionales. Esta falta de fundamento de los valores determina que el valor principal, casi único, sea el respeto formal a las reglas del juego democrático, esto es, la articulación de un procedimiento para reconducir el pluralismo existente a una manifestación común de voluntad.

$\mathrm{Y}$ es que, como señala Jiménez Campo ${ }^{18}$, «no existe límite ideológico de tipo alguno que pueda decirse derivado de la Constitución para constreñir la libre expresión del pluralismo", lo cual se traduce, además, en la posibilidad de reforma total del texto constitucional.

b) La falta de límites a la reforma constitucional y su proyección en el significado del pluralismo.

Para determinar el significado exacto del pluralismo en nuestro orden constitucional, a continuación trataremos este tema en relación con la ausencia en el Texto fundamental de 1978 de una cláusula de intangibilidad que establezca límite material alguno a la reforma constitucional. Además, para ilustrar esta significación constitucional compararemos la decisión del constituyente español con la del constituyente alemán de la postguerra mundial, pues a nuestro entender la diferente regulación parte de una distinta decisión constitucional básica acerca del fundamento jurídico-político del edificio dogmático constitucional.

En efecto, en la Constitución Española, a diferencia de lo que sucede en la Ley Fundamental de Bonn, no hay una cláusula de intangibilidad, con arreglo a la cual haya espacios vedados a la reforma constitucional.

Así, lo único que establece el art. $168 \mathrm{CE}$ es un procedimiento de reforma constitucional agravado, para el caso de que se pretendan reformar determinadas partes de la Constitución (Título Preliminar, Capítulo II, Sección $1^{\text {a }}$ del Título I, Título II), pero sin que haya límites materiales a la

18 J. Jiménez Campo. Voz Pluralismo político, en Temas Básicos de Derecho Constitucional, p. 122. 
reforma. Procedimiento agravado que implica que el proyecto de reforma deba ser aprobado por mayoría de dos tercios de cada Cámara con la inmediata disolución de las Cortes (art. 168.1), debiendo las Cámaras elegidas ratificar la reforma - de nuevo con la aprobación de dos tercios de las mismas (art. 168.2) - , que debe ser sometida a referéndum (art. 168.3).

No es esta la fórmula adoptada por el Constituyente alemán. De conformidad con el apartado 3 del art. 79 de la Ley Fundamental, "Ninguna reforma de la Ley Fundamental podrá afectar a la articulación de la Federación en Länder, al concurso fundamental de los Länder a la legislación o a los principios proclamados en los artículos 1 y 20 ".

Estos principios proclamados en los artículos 1 y 20 LF son la intangibilidad de la dignidad humana, los derechos del hombre como fundamento de la vida comunitaria, la vinculación de los poderes del Estado a los derechos humanos como derecho inmediatamente aplicable, así como el principio de Estado federal, democrático y social.

Esta diferente regulación, a nuestro entender, tiene su proyección en la ausencia -o no- de límites al pluralismo, o lo que es lo mismo, en el fundamento que a juicio de la Norma fundamental española o alemana tienen los valores ${ }^{19}$.

Asi, en el caso de la República Federal de Alemania no sólo no es admisible una reforma constitucional que pretenda afectar a los principios señalados anteriormente, sino que el orden constitucional constituye un límite al libre despliegue de la personalidad (art. 2.1 LF), determina que la libertad de cátedra no exima de la lealtad a la Constitución (art. 5.3 LF), implica la prohibición de las asociaciones dirigidas contra el orden constitucional o contra la idea del entendimiento entre los pueblos (art.9.2 LF), o que pueda perder los derechos de libertad de expresión, libertad de prensa, libertad de cátedra, libertad de reunión, de asociación, el derecho al secreto de la correspondencia, los servicios de correos y las telecomunicaciones, el derecho a la propiedad privada y al asilo quien abuse de los mismos para combatir el orden fundamental libre y democrático (art. 18 LF). Asimismo, la Ley Fundamental declara inconstitucionales "los partidos que, por sus fines o por la conducta de sus seguidores, se propongan

19 Aun cuando en la Ley Fundamental no existe un precepto comparable al art. 1.1 CE en lo que se refiere a la constitucionalización de los valores superiores del ordenamiento, es pacífica en la doctrina la consideración del ordenamiento constitucional alemán como un ordenamiento vinculado a los valores. Es más, el Tribunal Constitucional español ha seguido en este tema, en numerosas ocasiones, al Tribunal Constitucional Federal alemán. 
menoscabar o destruir el orden fundamental libre y democrático o poner en peligro la existencia de la República Federal de Alemania" (art. 21.2 LF).

A nuestro juicio, estas limitaciones al pluralismo - junto con los límites que a la reforma constitucional impone el art. $79.3 \mathrm{LF}-$ implican que el mismo tiene en la Constitución alemana un fundamento real, que no es otro que la consistencia de los valores, especialmente el supremo de la dignidad de la persona y sus derechos inherentes, valor intangible a la acción del poder, lo que significa que es previo al mismo ordenamiento y a la comunidad estatal (esto es, la dignidad de la persona, en la Ley Fundamental, es previa tanto al Estado-ordenamiento como al Estado-poder).

Desde esta óptica, el pluralismo (estrechamente conectado con el principio democrático) opera como criterio para determinar las exigencias concretas que el valor supremo (la dignidad de la persona y sus derechos inherentes) impone en cada momento histórico, correspondiendo al Estado-poder (cuyos órganos de dirección están formados por personas elegidas democráticamente) la elección de las alternativas para cada situación. La Constitución establecería, así, un equilibrio entre los principios fundamentales que deben ser respetados en todo caso y el margen necesario para que la acción política democrática pueda adaptarse a los cambios de circunstancias e ideas ${ }^{20}$.

De nuevo, como en el caso relativo a la existencia o no de un modelo constitucional de familia, me serviré de un ejemplo para ilustrar mi razonamiento ${ }^{21}$.

Así, y aun cuando en una Sentencia que ha sido objeto de crítica por parte de la doctrina, esta centralidad e intangibilidad de la dignidad de la persona ha llevado al Tribunal Federal de lo Contencioso Administrativo a mantener la tesis de que "la dignidad humana, cuya importancia está por encima de un individuo determinado, ha de ser asimismo defendida frente a la intención del afectado de realizar ciertas concepciones subjetivas en abierta desviación de la dignidad humana objetivamente considerada» ${ }^{22}$.

${ }^{20}$ Cfr. E. BendA. El Estado social de Derecho, Manual de Derecho Constitucional, p. 490 y ss.

${ }^{21}$ De la misma manera que los trabajos que defienden la eficacia frente a particulares de los derechos fundamentales deben recurrir a los casos en que los Tribunales han estimado esta eficacia, salvando las distancias creo que para entender la tesis que se sostiene en estas líneas es conveniente señalar ejemplos sobre los temas planteados.

22 BverwGE 64, 274 (280), en el llamado caso Peep Show. Precisamente por este argumento, a juicio del Tribunal federal de lo Contencioso Administrativo, la Ley puede prohibir la participación de una mujer en una exhibición, como si de una feria se tratara, aun cuando dicha participación sea voluntaria. Sentencia citada por Ernesto Benda. Dignidad humana y derechos de la personalidad, Manual de Derecho Constitucional, p. 144. 
Esto es, una consideración objetiva - con fundamento real más allá de la voluntad estatal o popular - de la dignidad de la persona constituye un límite claro al derecho a la autodeterminación personal o al libre desarrollo de la personalidad.

Y es que, la proyección del valor de la dignidad de la persona en el Estado material de derecho implica establecer límites a la decisión mayoritaria, pues la mayoría democrática no está sólo limitada por el respeto a las formas jurídicas, sino que no decide con carácter absoluto, no dispone de una competencia global, ni el resultado de su decisión puede considerarse, eo ipso, justo ${ }^{23}$.

Por el contrario, en el caso de España no hay en la Constitución de 1978 precepto alguno que establezca algún tipo de límite a la reforma constitucional o al pluralismo, lo que determina que no haya - más allá de los límites penales, de mera legalidad-posibilidad de establecer límites a la autodeterminación personal pluralista $o$ a los fines perseguidos por las asociaciones o partidos ${ }^{24}$.

No hay limites en la Constitución a los objetivos o fines - las ideasque pueda defender un partido o una asociación, por lo que no puede haber partidos inconstitucionales en razón de su programa, como el reciente debate con motivo de la Ley de Partidos Políticos (Ley Orgánica 6/2002, de 27 de junio; BOE de 28 de junio de 2002) ha puesto de manifiesto ${ }^{25}$.

En esta Ley de Partidos, asi, se insiste en que son admisibles todas las ideas y programas, de manera que un partido puede perseguir cualesquiera fines, aun cuando impliquen la revisión del propio marco institucional, siempre que se haga "con un respeto escrupuloso de los métodos $y$ principios democráticos», admisibilidad de todo tipo de ideas o doctrinas que trae causa, precisamente, de "la libertad inherente al máximo grado de pluralismo» -en expresión de la propia Exposición de Motivos, en su apartado IV-.

Por tanto, es la proyección del pluralismo político (valor superior del ordenamiento, ex art. 1.1 CE) la que lleva a considerar lícita cualquier idea,

${ }^{23}$ Cfr. E. BendA. El Estado social de derecho, Manual de Derecho Constitucional, p. 496.

${ }^{24}$ Así, el art. $515 \mathrm{CP}$, al tipificar las asociaciones ilícitas (en las que, como especie del género asociación entran los partidos políticos, sin perjuicio de su regulación en la nueva Ley de Partidos), sólo considera punibles aquellas que realicen determinadas conductas que atentan contra los derechos de terceros.

${ }^{25}$ Cfr. Manuel JIMÉNEZ de PARGA, EITC español y el TC alemán, artículo publicado en $A B C$ el día 5 de mayo de 2002. 
doctrina o programa, "por más que éstas se alejen o incluso pongan en cuestión el marco constitucional» (apartado IV de la Exposición de Motivos).

$Y$ es que en nuestro ordenamiento, como ha puesto de manifiesto en varias ocasiones el Tribunal Constitucional ${ }^{26}$, no hay límites a la libertad ideológica, siempre y cuando se respete -en las manifestaciones externas de esa ideologia - la propia Constitución y el resto del ordenamiento juridico; y esto es así precisamente por el valor del pluralismo político unido a la ausencia de cláusula de intangibilidad en la Norma fundamental. De hecho, el Tribunal Constitucional ha señalado que "la fidelidad a la Constitución (...) puede[n] entenderse como el compromiso de aceptar las reglas del juego político y el orden jurídico existente en tanto existe y a no intentar su transformación por medios ilegales» ${ }^{27}$.

En consecuencia, cuando el apartado 2 del art. 9 de la Ley de Partidos señala cuándo puede procederse a la ilegalización de un partido político, dispone que será "cuando su actividad vulnere los principios democráticos, particularmente cuando con la misma persiga deteriorar o destruir el régimen de libertades o imposibilitar o eliminar el sistema democrático, mediante alguna de las siguientes conductas, realizadas de forma reiterada y grave».

A estas consideraciones sobre el significado de la ausencia de límites a la reforma constitucional llega también el Tribunal Constitucional en su Sentencia 48/2003, de 12 de marzo, dictada precisamente con motivo del Recurso de inconstitucionalidad presentado contra la Ley de Partidos Políticos. Así, el Tribunal, señaló que "sólo incurre en causa de disolución el partido que, no en su ideología, sino en su actividad persiga efectiva $y$ actualmente deteriorar o destruir el régimen de libertades" (F. J. 10).

Es cierto que la redacción del art. 9.3.c) de la Ley de Partidos Políticos podría hacer pensar que hay algunos fines que el ordenamiento considera ilegítimos $^{28}$, pero en relación con este precepto, el Tribunal Constitucional (en esta Sentencia de 12 de marzo de 2003) ha señalado que (F. J. 13) que "la alusión a los fines terroristas ha de entenderse ceñida sólo a los fines inmediatos de perturbar la paz, generalizar el miedo, etc. y no a la ideología del partido».

26 Por ejemplo, en la STC 119/1990, de 21 de junio, en la que concede el amparo a los diputados de HB que no prestaron juramento a la Constitución.

${ }^{27}$ STC 122/1983, de 16 de diciembre.

${ }^{28} \mathrm{El}$ art. 9.3 de la Ley de Partidos señala que: «Se entenderá que en un partido político concurren las circunstancias del apartado anterior cuando se produzca la repetición o acumulación de alguna de las conductas siguientes:... c) Incluir regularmente en sus órganos directivos o en sus listas electorales personas condenadas por delitos de terrorismo que no hayan rechazado públicamente los fines y los medios terroristas...)". 
Como puede observarse, es la actividad, la realización de determinadas conductas de apoyo, justificación o amparo a otras conductas tipificadas como ilícitos penales lo que determina la posibilidad de ilegalizar un partido, por considerarse que esa actividad vulnera el respeto al pluralismo exigible a los partidos (art. 9.1 de la Ley de Partidos).

Lo mismo sucede con la criminalización de determinadas conductas de apoyo al terrorismo, tipificadas en la reforma del Código Penal llevada a cabo mediante la Ley Orgánica 7/2000, de 22 de diciembre. En el apartado III de la Exposición de Motivos de dicha norma se precisa, de forma análoga a la de la Ley de Partidos, que "No se trata, con toda evidencia, de prohibir el elogio o la defensa de ideas o doctrinas, por más que éstas se alejen o incluso pongan en cuestión el marco constitucional, ni, menos aún, de prohibir la expresión de opiniones subjetivas sobre acontecimientos históricos o de actualidad».

$\mathrm{Y}$, en consecuencia, el art. $578 \mathrm{CP}$, en la redacción que le da dicha Ley Orgánica $7 / 2000$, lo que tipifica es la realización de conductas ofensivas para las víctimas del terrorismo, ya sea porque constituyen actos directamente humillantes para las mismas como porque impliquen el enaltecimiento o la justificación de actos tipificados como delitos o de las personas que los hayan cometido.

Por lo que respecta a la autodeterminación personal, tampoco hay en la Constitución de 1978 límite alguno al pluralismo, más allá del respeto a los derechos de los demás. El pluralismo, proyectado en la libertad ideológica, se refleja en la posibilidad de adoptar ante la vida la posición que cada uno estime conveniente, así como en representar o enjuiciar la realidad según las convicciones personales ${ }^{29}$, aun cuando eso implique equivocarse, pues en virtud del pluralismo cabe un "derecho al error» ${ }^{30}$.

Es más, la proyección del valor pluralismo, unido a la libertad ideológica y de conciencia, hace que, en términos jurídicos, no pueda hablarse propiamente de error, pues esa expresión implicaría ya una mayor consideración hacia determinadas ideas o concepciones del hombre $y$ del mundo. Y en el ámbito personal, en la medida en que la Constitución reconoce el derecho al libre desarrollo de la personalidad, y tal $y$ como hemos visto que sucede en relación con los partidos políticos, no puede calificarse un comportamiento que no afecte a terceros como más valioso que otro, pues comportaría una vulneración de la neutralidad estatal que se deriva de la libertad ideológica y religiosa.

${ }^{29}$ Cfr. STC 137/1990, de 19 de julio.

${ }^{30}$ Cfr. T. de LA Quadra. La cláusula de conciencia, un Godot constitucional. En el Libro Homenaje al Prof. Villar Palasí. Civitas, Madrid, 1989. 
Ahora bien, esta neutralidad estatal afecta a la vida comunitaria y plantea algunos problemas al Derecho constitucional, como son, en primer lugar, la cuestión de si existen o no límites a la decisión de la mayoría democrática - pues precisamente en virtud de esa neutralidad estatal el contenido del ordenamiento debe ser determinado según los principios del consenso y de la regla de las mayorías-, y, en segundo lugar, dado que el derecho a la libertad ideológica y religiosa conlleva el derecho a actuar de acuerdo con los dictados de la conciencia personal formada según las propias convicciones, la cuestión de la obediencia a las normas que impongan una conducta contraria a las creencias subjetivas de los ciudadanos. Problemas éstos que se encuentran atravesados por la cuestión de quién y cómo - con qué criterios - fija el mínimo común ético que necesita toda sociedad. A estos asuntos dedicaremos los próximos epígrafes.

\section{c) Pluralismo y neutralidad estatal}

Una de las manifestaciones más importantes del reconocimiento del pluralismo como un valor jurídico de rango constitucional es la neutralidad estatal, conectada también con la libertad religiosa e ideológica (art. 16 CE).

Aun cuando un estudio en profundidad de este tema excede del ámbito de estas líneas, por la relación con el objeto de las mismas sí que es oportuno, a nuestro entender, hacer alguna referencia a la cuestión de la neutralidad estatal.

Es bien sabido que los principios de libertad religiosa e ideológica traen causa de la fragmentación religiosa primero, ético-valorativa después, que trajo como consecuencia la Reforma protestante, que acabó con la unidad religiosa de los nacientes Estados europeos.

Si bien en un primer momento rigió la doctrina con arreglo a la cual la religión del Príncipe era la religión del pueblo, posteriormente se llegó a un criterio de tolerancia de la disidencia religiosa, y como consecuencia de la misma y con el nacimiento del liberalismo, a la consagración del pluralismo en la vida social.

Esta consagración del pluralismo lleva a la consideración de que el Estado tiene que ser neutro en las cuestiones religiosas e ideológicas, neutralidad que permite la identificación de todos los ciudadanos, cualesquiera sean sus convicciones, con el Estado ${ }^{31}$. En este contexto de neutralidad

31 Cfr. M. J. Roca. La neutralidad del Estado: fundamento doctrinal y actual delimitación en la Jurisprudencia. Revista Española de Derecho Constitucional núm. 48, sep- 
estatal, corresponde al Estado respetar unas esferas de libertad en la vida privada de las personas - en las que cada una puede buscar la felicidad y autorrealización con arreglo a sus concepciones subjetivas ${ }^{32}-, y$ ordenar la convivencia - más bien coexistencia - con el sometimiento de los ciudadanos a unas mismas leyes iguales para todos en lo político y social ${ }^{33}$. Este es el fundamento doctrinal del constitucionalismo moderno, vinculado a la idea de democracia en libertad como Estado de los ciudadanos fundado en leyes de libertad ${ }^{34}$, de manera que la actividad de los entes públicos, especialmente en el ámbito de la enseñanza, debe estar guiada por esta neutralidad ideológica ${ }^{35}$.

Esta neutralidad del Estado, reverso de la libertad ideológica y religiosa, es la que hace posibles - en opinión de nuestroTribunal Constitucional los valores superiores de nuestro ordenamiento jurídico que se propugnan en el art. 1.1 CE. Asi, para que la libertad, la justicia, la igualdad y el pluralismo politico sean una realidad efectiva es preciso que a la hora de regular conductas $y$, por tanto, de enjuiciarlas, se respeten aquellos valores superiores sin los que no se puede desarrollar el régimen democrático. El propio Tribunal Constitucional vincula de tal modo libertad ideológica y pluralismo político (en la STC 20/1990, de 15 de febrero, habla de "indisoluble unidad") que es desde los presupuestos de la libertad ideológica desde donde se deben interpretar los valores y la propia Constitución ${ }^{36}$.

En efecto, con arreglo a esta neutralidad estatal, dentro de la vida social conviven las distintas creencias y convicciones (religiosas o ideológicas) presentes en una sociedad «plural y democrática» ${ }^{37}$.

tiembre-diciembre de 1996. Roca cita la siguiente expresión delTribunal Constitucional federal alemán: La neutralidad estatal tiene como función "hacer posible que cualquier ciudadano pueda identificarse con su Estado, sólo así el Estado puede ser hogar de todos los ciudadanos", p. 253-254.

32 Es el campo de la autonomía moral kantiana.

${ }^{33}$ Este es en síntesis el origen del Estado de Derecho. Cfr. C. Fernández de la Cigoña Cantero. La aparición del Estado de Derecho. Su filosofía jurídica y política. En la obra colectiva El Estado de Derecho en la España de hoy, que recoge las ponencias de un Seminario sobre esta cuestión de la Sección de Filosofía del Derecho de la Real Academia de Jurisprudencia y Legislación. Actas, Madrid, 1996.

${ }^{34} \mathrm{Cfr}$. W. MAlHofer. Principios de una democracia en libertad, Manual de Derecho Constitucional, p. 241 y ss.

35 STC 5/1981, de 13 de febrero. El Tribunal Constitucional dijo expresamente en esta Sentencia que "todas las instituciones públicas, y muy especialmente los centros docentes, han de ser ideológicamente neutrales».

${ }^{36}$ Cfr. F. FERnÁNDEZ SEgADo. El régimen constitucional español. Dykinson, Madrid, 1992.

${ }^{37}$ STC 177/1996, de 11 de noviembre. 
Por otra parte, y en conexión con el pluralismo político, el Tribunal Constitucional español ha extraido otra consecuencia del principio de neutralidad estatal, especialmente en lo relativo a la autonomía de la conciencia subjetiva y la interdicción de una proyección política y jurídica de los vínculos religioso-metafísicos dentro de la sociedad. Así, por ejemplo, en la Sentencia en que otorga el amparo a los diputados de Herri Batasuna que se negaron a jurar o prometer la Constitución, a pesar de imponerlo como obligación el Reglamento del Congreso de los Diputados, el Tribunal $^{38}$ descarta que haya que entender el juramento o promesa como adición de un vínculo religioso o moral al exclusivamente jurídico de sujeción a la Constitución (que deriva, para todos los ciudadanos y los poderes públicos, del art. 9.1 de la Norma fundamental). $Y$ es que, a juicio del Tribunal, la fidelidad que es exigible en relación con la Constitución se limita a la obligación de obedecer los procedimientos democráticos y las reglas de juego en ella contenidas, dentro del ordinario deber de sujeción a la Constitución y al resto del ordenamiento jurídico, sin que implique una adhesión interna al orden constitucional ${ }^{39}$.

Esta neutralidad del Estado respecto de las convicciones religiosas e ideológicas, con las proyecciones que acabamos de comentar, late también en numerosas Resoluciones de organismos internacionales. Así, por ejemplo, en su Recomendación Parlamentaria de 2 de febrero de 1993, el Consejo de Europa considera que uno de los principios de la democracia occidental es la primacia del derecho laico. Asimismo, en su Sentencia de 31 de julio de 2001, el Tribunal Europeo de Derechos Humanos une democracia, pluralismo y neutralidad estatal en relación con las diversas concepciones religiosas e ideológicas ${ }^{40}$.

38 STC 119/1990, de 21 de junio.

39 STC 122/1983, de 16 de diciembre. El Tribunal, literalmente, señala que: "La fidelidad, en esta línea interpretativa, no entraña una prohibición de representar y de perseguir ideales politicos diversos de los encarnados en la Constitución y en el Estatuto, siempre que se respeten aquellas reglas de juego, y no supone, por tanto, una renuncia a las libertades individuales consagradas por la Constitución ni a la libre crítica del ordenamiento jurídico existente, ni de los actos políticos que se realicen, ni a la libre proposición de nuevas leyes, ni a procurar la reforma de la Constitución o el Estatuto, tanto más, conviene subrayarlo, cuanto el contenido de la actual Constitución Española es reformable, aunque el procedimiento para llevar a cabo esa reforma sea mas o menos rigido, según la materia y ámbito a que afecte, como lo es el Estatuto de Galician.

${ }^{40}$ Sentencia en que considera ajustada al Convenio del Consejo de Europa para la protección de los derechos humanos y las libertades fundamentales la decisión del Tribunal Constitucional turco de disolver el Partido de la Prosperidad, partido islamista que propugnaba para Turquía la adopción de un sistema político multijurídico basado en diferentes creencias y la aplicación de la Ley Islámica (la Sharia) a la comunidad musulmana. Cfr. L. MarTíNRetortillo. La ilegalización del Partido de la Prosperidad o de cómo se conjuró el riesgo de "Yihad». Diario ABC, 21 de abril de 2002. 
En esta línea, señala dicho Tribunal que "no hay democracia sin pluralismo", y que este pluralismo no es sólo de partidos, sino también de ideas, pues «la libertad de pensamiento, de conciencia y de religión representa uno de los cimientos de una sociedad democrática en el sentido del Convenio». A este respecto, añade sobre tal libertad que "figura, en su dimensión religiosa, entre los elementos más esenciales de la identidad de los creyentes y de su concepción de la vida pero es también un bien precioso para los ateos, los agnósticos, los escépticos o los indiferentes. Va en ello el pluralismo -duramente conquistado a lo largo de los siglos-consustancial a tal sociedad".

Esto es, el Tribunal Europeo de Derechos Humanos entiende el pluralismo como pluralidad de concepciones de la vida, multiplicidad de «imágenes del hombre», todas las cuales deben quedar amparadas por el Estado de derecho propio de una sociedad democrática, Estado que, en cuanto garante de los derechos y libertades individuales, es uorganizador imparcial del ejercicio de las diversas convicciones y religiones en una sociedad democrática».

Ahora bien, esta neutralidad del Estado - que implica un reconocimiento de la diversidad de concepciones del mundo presentes en una sociedad - no excluye la necesidad de que existan, en la vida social, unos valores compartidos, pues una sociedad, por plural que sea, sigue necesitando una cierta homogeneidad ética.

De hecho, el Tribunal Constitucional español ${ }^{41}$, aun admitiendo un "legítimo pluralismo en orden a la formación moral", tiene en cuenta la necesidad de otorgar relevancia jurídica a la moral pública "como elemento ético común de la vida social",, relevancia jurídica que consiste en la posibilidad de que la moral pública limite el ejercicio de algún derecho fundamental, en la medida en que "es necesario un mínimum ético para la vida social».

El problema que se le plantea al Tribunal, y que no es sino manifestación de la aporía de cómo evitar desde los presupuestos del constitucionalismo liberal-democrático que el pluralismo de las sociedades occidentales contemporáneas haga imposible la integración estatal y la misma vida comunitaria, es precisamente encontrar un criterio que permita establecer los límites del "legítimo pluralismo", pues la atomización moral hace imposible la misma vida comunitaria plural ${ }^{42}$.

41 STC 62/1982, de 15 de octubre, en la que admite la moral pública como límite de los derechos fundamentales.

42 Cfr. F. Puy Muñoz. Pluralismo en la Constitución de 1978 y el art. 1.1. Op. cit. 
A este respecto, a nuestro entender es oportuno reproducir de nuevo la cita de Conrado Hesse en que dicho autor, refiriéndose a la función de integración de la Constitución, señala cómo "allí donde, partiendo de la pluralidad de voluntades, ya no es posible formar una voluntad conjunta vinculante quiebra el Estado como unidad política de acción»" ${ }^{43}$.

Esta necesidad de poner algún límite al pluralismo ha sido resaltada por gran parte de la doctrina. Así, por ejemplo, para evitar que el pluralismo afecte negativamente a la vida colectiva, Lucas Verdú ${ }^{44}$ considera que debe ser reconducido a una cierta unidad, para que no sea un elemento disgregador $y$, por tanto, disvalioso.

Lo mismo consideran Parejo Alfonso ${ }^{45}$, o López Pina ${ }^{46}$, para quienes esa necesaria reconducción a la unidad viene dada por el consenso social fundamental (especialmente en el momento constituyente) sobre cuestiones como la dignidad humana, derechos individuales, Estado social, división de poderes, etc. En este sentido, como asume de la doctrina alemana Roca 47 , "el Estado moderno vive de presupuestos que no puede garantizar él mismo".

No es este el momento de entrar en la cuestión de los problemas que plantea el consenso como criterio definidor de los presupuestos éticos de la vida común. Pero sí es oportuno resaltar la aporía con que se encuentra el Derecho Constitucional, precisamente por sus presupuestos negadores de toda metafísica, y a pesar del intento de apertura axiológica que implican cláusulas como la del art. 1.1 CE.

En efecto, aun cuando consideró que la moralidad pública en tanto que elemento ético común de la vida social puede constituir un límite a los derechos fundamentales (y muy especialmente si está en juego la formación de la juventud o la protección de los menores), el Tribunal Constitucional se vio en la obligación de precisar que la moral pública es "susceptible de concreciones diferentes, según las distintas épocas y países, por lo que no es algo inmutable desde una perspectiva social».

43 C. Hesse. Constitución y Derecho constitucional, Manual de Derecho Constitucional, p: 3.

44 P. Lucas Verdú. Comentario al art. 1 CE. En Comentarios a las Leyes Políticas.

45 L. PAREJo Alfonso. Constitución y valores del ordenamiento, $p$.

46 Prólogo a la obra colectiva (editada por el propio López Pina) División de poderes e interpretación. Hacia una teoría de la praxis constitucional, Tecnos, Madrid, 1987.

47 La neutralidad del Estado: fundamento doctrinal y actual delimitación en la Jurisprudencia, op. cit., p. 261-262 
$Y$ es que la consagración del pluralismo hace que la cuestión del establecimiento del mínimo ético común necesario para la vida social haya recaido en los Tribunales $y$, en la medida en que se conecta ese mínimo ético con los valores constitucionales, en el Tribunal Constitucional. En la obra anteriormente citada, López Pina - hablando de Estados Unidosseñala lo siguiente: "El pluralismo ideológico colocó sobre la agenda de la justicia la tarea de proclamar los criterios morales de la sociedad; y asi los tribunales reemplazaron a las Iglesias y los partidos -entre sí neutralizados por el reconocimiento cultural y legal del pluralismo- en la tarea de definir los parámetros morales de la cultura».

Así, en relación con la determinación de este minimo ético común necesario para la vida social, corresponde al Tribunal Constitucional señalar con carácter vinculante qué ha querido decir el constituyente, y por esta vía, fijar esos parámetros morales sobre los que se asienta el entramado jurídico-político del Estado, pues como señaló en su Sentencia 76/1983, de 5 de agosto, es tarea del Tribunal «custodiar la permanente distinción entre la objetivación del poder constituyente y la actuación de los poderes constituidos».

Esta cuestión cobra una especial relevancia en el momento presente, cuando se le plantean nuevos retos al Derecho Constitucional, como son garantizar que los adelantos de la tecnología genética y de las ciencias en general no vayan en menoscabo de la dignidad de la persona. Así, cuestiones como la licitud de la clonación terapéutica, la experimentación con "embriones sobrantes», etc., se presentan como problemas que antes o después deberá abordar el Derecho Constitucional. Igual que tendrá que dar respuestas en relación con aquellos asuntos donde es más notoria la fragmentación moral de nuestras sociedades pluralistas, tales como el aborto, la eutanasia, la equiparación de matrimonio y parejas de hecho, el concepto de familia constitucionalmente garantizado, la adopción por homosexuales... En todos estos temas, al final, quien tiene que decidir es el Tribunal Constitucional, que de esta forma define los parámetros morales de nuestra sociedad.

El problema no es que tenga que decidir el Tribunal Constitucional alguien tiene que decidir en última instancia - sino que, aunque teóricamente tendría que hacerlo, no puede decidir con criterios estrictamente jurídicos, pues la admisión del pluralismo sin límites que se desprende de las Sentencias que hemos comentado (ejemplarmente, en la que señala que no hay un modelo de constitucional de familia) determina que no quepa hallar un fundamento real (metafísico, cognoscible por la razón, si bien en el ámbito problemático y prudencial propio de la razón práctica) a los valores. Un ejemplo de ello es el de la STC 53/1985 sobre el aborto, cri- 
ticada por ser una sentencia que argumenta con criterios morales y no jurídicos. Crítica que viene tanto de quienes consideran lícita la despenalización del aborto (a este respecto son significativos los Votos particulares ${ }^{48}$ ) como de quienes son partidarios del derecho a la vida del nasciturus ${ }^{49}$.

Antes de seguir con el hilo de la exposición merece la pena que nos detengamos, siquiera sea un momento, en las críticas que se han hecho a esta STC 53/1985 por parte de quienes consideran al nasciturus titular del derecho a la vida, por cuanto nos permite ilustrar nuestra tesis. Así, Fernández Segado pone de manifiesto cómo el Tribunal, después de señalar que el nasciturus es un tercero distinto de la madre (pues la vida humana comienza con la gestación), contra los criterios de la lógica no considera que el nasciturus sea titular del derecho a la vida (lo que determinaría, por propia coherencia, la emisión de un fallo de inconstitucionalidad de la Ley, como señala en su Voto particular el Magistrado don Francisco Tomás y Valiente). Al no considerar al nasciturus titular del derecho fundamental a la vida, y para evitar la completa desprotección del no nacido, el Tribunal recurre a argumentos éticos (el valor superior de la vida humana). En función de esa razón ética sobre el valor de la vida, el Tribunal concluye que el nasciturus es un bien constitucionalmente protegido (al igual que el Tribunal Constitucional federal alemán recurrió a la concepción dogmática de los bienes juridicos en conflicto ${ }^{50}$ ). Razonamiento que acaba con la esencial distinción jurídica entre "personas" $y$ "cosas», convirtiendo al propio hombre en un bien. Algo similar, por cierto, a lo que sucede en las

48 Especialmente el del Magistrado don Francisco Tomás y Valiente, que expresamente señala "nunca he sido un entusiasta de la filosofía de los valores», para a continuación mostrar los saltos lógicos del razonamiento delTribunal. En idéntico sentido, los Votos particulares de los Magistrados don Luis Díez Picazo ( «En lo que llamo deducciones constructivas hay larvados o manifiestos juicios de valor, porque se puede tener la impresión de que se segrega una segunda línea constitucional, que es muy dificil que opere como un límite del poder legislativo, en quien encarna la representación de la soberanía popular») y don Francisco Rubio Llorente ("Con esta decisión la mayoría... opera como si el Tribunal Constitucional fuese una especie de tercera Cámara, con facultades para resolver sobre el contenido ético o la oportunidad política de las normas aprobadas por las Cortes Generales»).

${ }^{49}$ Asi, por ejemplo, F. Fernández Segado. El derecho a la vida en la Jurisprudencia constitucional, en Revista General de Legislación y Jurisprudencia 6/1986. Cfr. También, Miguel Ángel Alegre, Apuntes sobre el derecho a la vida en España: Constitución, Jurisprudencia y Realidad, Revista de Derecho Político de la UNED, núm. 53, 2002.

${ }^{50} \mathrm{G}$. Rodriguez Mourullo. La Sentencia delTribunal Constitucional español desde las perspectivas constitucional y penal, División de poderes e interpretación. Hacia una teoria de la praxis constitucional, Tecnos, Madrid, 1987, p. 191. 
Leyes sobre técnicas de reproducción asistida y de donación y utilización de embriones $y$ fetos humanos o de sus células, tejidos u órganos ${ }^{51}$. Consecuencia todo ello de la falta de fundamentación metafísica del Derecho, por despreciar el fundamento real de los valores superiores del ordenamiento, especialmente de la dignidad de la persona ${ }^{52}$.

La cuestión es que este desplazamiento de la determinación del mínimo ético común a la labor de interpretación del Juez de la Constitución plantea el problema de caer en el subjetivismo judicial, precisamente por la razón - antes apuntada - de que no puede decidir con criterios jurídicos. No sólo al subjetivismo del Tribunal Constitucional, sino al subjetivismo judicial en sentido estricto, pues gracias al principio de la interpretación conforme a la Constitución y la obligación que señala al respecto el art. 5.1 LOPJ, los jueces podrían llegar a interpretar la ley en contra de la propia ley, en la medida en que esa interpretación fuera la "conforme con la Constitución ${ }^{53}$.

De nuevo aquí, y para solucionar un tema jurídico, pues afecta a la interpretación constitucional, nos encontramos con la cuestión de cuál es el fundamento del pluralismo y del resto de los valores, pues para evitar este subjetivismo judicial, De la Quadra señala que corresponde al poder legislativo (donde entran en acción los partidos políticos, que "expresan el pluralismo político, concurren a la formación y manifestación de la voluntad popular y son instrumento fundamental para la participación política", según el art. $6 \mathrm{CE}$ ), y precisamente mediante el juego del pluralismo político, concretar los preceptos indeterminados (en la medida en que reflejan un consenso mínimo) de la Constitución.

Con esto, y dado que corresponde al legislador democrático el concretar ese consenso fundamental, tenemos que enfilar la cuestión de la democracia en nuestro orden constitucional.

51 Leyes 35/1988, de 22 de noviembre, y 42/1988, de 28 de diciembre, y las Sentencias que resuelven los recursos de inconstitucionalidad presentados contra las mismas (SSTC 212/1996, de 19 de diciembre, y 116/1999, de 17 de junio). Cfr. C. Fernández de la Cigoña Cantero. La dignidad de la persona en la legislación genética española, Verbo, núm. 323-324, marzo-abril de 1994.

52 Cfr. M. Ayuso TorRes. El ágora y la pirámide. Una visión problemática de la Constitución Española, p. 130 y ss.

${ }^{53} \mathrm{Cfr}$. T. DE LA QUADRA. La Constitución como norma suprema y la seguridad jurídica, División de poderes e interpretación. Hacia una teoría de la praxis constitucional, p. 140. 


\section{PLURALISMOY DIGNIDAD DE LA PERSONA.}

\section{a) Democracia y norma fundamental de la Constitución.}

La Constitución española, a semejanza de lo que ocurre en la Ley Fundamental de Bonn, pese a consagrar el principio de Estado democrático y reconocer la soberanía popular ${ }^{54}$, esto es, el pueblo como origen del poder, no define claramente qué entiende por democracia. Como han puesto de relieve Hesse y Maihofer en relación con la Ley Fundamental ${ }^{55}$, hay pocos conceptos constitucionales que hayan sido interpretados de forma más diversa que el de democracia, interpretación que en modo alguno puede decirse que carezca de trascendencia.

Asi, y con importantes consecuencias prácticas para lo que constituye el objeto de estas líneas, no es lo mismo considerar el principio democrático referido únicamente al método de designación de los titulares de. los órganos de cada uno de los poderes del Estado así como a la participación ciudadana en la vida colectiva (intervención en la elaboración de disposiciones administrativas que afecten a sus derechos - art. $105 \mathrm{CE}-$ derecho de acceso a registros y archivos, participación de organismos sociales por medio del Consejo Económico y Social, etc.), que, como alternativa, considerar la democracia como principio de convivencia a partir de una concepción plural de la sociedad.

En el primer caso, la regla de las mayorías se encuentra limitada por el consenso constituyente fundamental, mientras que en el segundo caso, ese consenso estaría abierto y necesitado de una constante actualización precisamente por medio de dicha regla de mayorías. En el fondo, de lo que. se trata es de ver cuál es la verdadera norma fundamental recogida en la Constitución, el arco de bóveda a partir del cuál explicar el conjunto del edificio jurídico-político constituido en 1978.

Si esta norma fundamental es el art. $10 \mathrm{CE}$, esto es, la dignidad de la persona y los derechos a ella inherentes, "fundamento del orden político $y$. de la paz social", la Constitución impondría unos límites materiales - ade-

54 A pesar de que el art. 1.2 CE señala que "La soberanía nacional reside en el pueblo español del que emanan los poderes del Estadon, es pacífico en la doctrina el considerar que se está afirmando el principio de soberanía popular, y no el de soberanía nacional acuñado en el siglo XIX como limitación a la potestad soberana del pueblo. Al respecto, cfr. A. GaRRORENA. El Estado español como Estado social y democrático de derecho. Tecnos, Madrid, 1984.

55 W. MAlHofer. Principios de una democracia en libertad, Manual de Derecho Constitucional, p. 219. 
más de formales - al poder, mientras que si consideramos que dicha norma fundamental es la contenida en el art. $1 \mathrm{CE}$, como sostiene la teoría democrática, la soberanía popular determinaría quién, cómo y, sobre todo, qué se manda ${ }^{56}$. En este segundo caso, esta afirmación de la soberanía popular nos llevaría a considerar la inexistencia de límites materiales a la decisión por mayorías, quedando únicamente los límites formales.

En una primera aproximación a la cuestión planteada, parece que la Constitución opta por la centralidad de la dignidad de la persona, en la medida en que la considera como el fundamento del orden político y de la paz social (art. 10.1 CE). Dignidad de la persona que, aun no siendo uno de los valores positivizados en el art. 1.1 CE, tiene el mismo rango constitucional que estos. De hecho, en la medida en que los derechos fundamentales de la persona son inherentes a su dignidad ${ }^{57}$, y el ordenamiento jurídico que nace de la Constitución se considera vinculado a los derechos fundamentales, la dignidad se nos presenta como un principio rector del orden jurídico y como base y fundamento del completo ordenamiento jurídico ${ }^{58}$.

Lógicamente, esta centralidad de la dignidad de la persona no implica desconocer el carácter de la norma de apertura contenida en el art. $1 \mathrm{CE}$, sino que consiste en reconocer ambas disposiciones (arts. 1 y $10.1 \mathrm{CE}$ ) como principios constitucionales que dotan de unidad de sentido al orden jurídico-político de nuestro Estado ${ }^{59}$.

En esta labor de dotar de unidad de sentido al orden jurídico-político, la dignidad de la persona, valor supremo en el plano sustantivo y material, sería la síntesis de las relaciones y tensiones entre las cláusulas de Estado de derecho, por un lado, y de Estado social y democrático, por otro.

Esta síntesis, necesaria en la medida en que el orden constitucional es un todo dinámico que no puede ser entendido o interpretado de manera fragmentada, implica una cierta limitación del principio democrático $y$ de la capacidad de configuración de la soberanía popular.

56 Cfr. E. VIDAL GIL. Los límites a la decisión por mayorías y la norma fundamental de la Constitución española, en Homenaje a Joaquín Tomás de Villarroya, Fundación Valenciana de Estudios Avanzados, Valencia, 2000.

57 E. BENDA considera que los derechos serian "porciones autónomas derivadas de la dignidad humana». Cfr. Dignidad humana y derechos de la personalidad, Manual de Derecho Constitucional, p. 122.

58 Cfr. J. GonzAlez Pérez. La dignidad de la persona. Civitas, Madrid, 1986.

59 Cfr. F. Fernández Segado. La dogmática de los derechos humanos. Ediciones Jurídicas, Lima, Perú, 1994. 
Así, para que la afirmación de este principio de la soberanía popular $y$ de la cláusula de Estado democrático no conlleve la desnaturalización de la: cláusula del Estado de derecho, la proclamación como principio constitucional básico de la dignidad de la persona excluye la democracia y la aplicación de la regla de las mayorías de aquellos ámbitos que no le son propios (precisamente, los que son expresión de esta dignidad de la persona ${ }^{60}$.

De esta manera, en el orden complejo de valores que podemos encontrar en la Constitución, podriamos distinguir entre un valor sustantivo o material, que sería la dignidad de la persona como fundamento del orden dogmático-constitucional (art. 10.1 CE), un valor de naturaleza formal-organizativa, expresado en la fórmula «Estado social y democrático: de derecho»(art. 1.1 CE) y los valores superiores del ordenamiento jurídico: (art. 1.1 CE, in fine), cuya función principal sería dar configuración jurídica: a las dos realidades, sustantiva y organizativa ${ }^{61}$.

Esta primacía de la dignidad de la persona parte de la constatación de que nuestro orden constitucional, si bien es fruto de un consenso, no se apoya en un relativismo axiológico que deba ser articulado únicamente mediante un sobrevalorado principio democrático en tanto que expresión del pluralismo ${ }^{62}$, sino que en el sistema material de valores que consagra la Constitución lo primero es la dignidad de la persona, afirmación de la: que cabe extraer incluso la existencia de un deber genérico de respeto de los derechos propios y ajenos y de protección de la persona ${ }^{63}$.

Esto es, si bien en la acción del Estado-poder prima el elemento democrático, en la proyección en la vida de los ciudadanos del Estado-ordenamiento prima la dignidad de la persona, que de esta forma limita el pluralismo y la regla de las mayorías. Esto es, si la acción del Estado es reflexiva, y está dirigida a la propia organización del poder o a la toma de decisiones políticas, debe primar el elemento democrático (en virtud de la soberanía popular, del principio de participación ciudadana y de la aplicación del valor pluralismo). Si, en cambio, esta acción del Estado incide en el ámbito más propio de la persona, el elemento democrático debe ceder ante el elemento garantizador contenido en la cláusula de Estado de derecho como poder limitado ${ }^{64}$.

${ }^{60}$ Cfr. F. González Navarro. El Estado social y democrático de Derecho. EUNSA, Pamplona, 1992.

61 Cfr. L. PAREjo Alfonso. Constitución y valores del ordenamiento, op. cit., p 137 y ss.

62 Cfr. L. PAREJo. Estado social y Administración Pública. Los presupuestos constitucionales de la reforma administrativa. Civitas, Madrid, 1983.

${ }^{63}$ Cfr. M. A. Alegre Martinez. La dignidad de la persona como fundamento del ordenamiento constitucional español. Universidad de León, 1996, p. 87.

${ }^{64}$ Cfr. L. Parejo Alfonso. Constitución y valores del ordenamiento, op. cit., p. 138. 
Esta interpretación parece presente en algunas Sentencias del Tribunal Constitucional especialmente importantes.

Así, en la STC 53/1985, de 11 de abril, con ocasión de la despenalización del aborto en tres supuestos, el Tribunal señaló que

"Junto al valor de la vida humana y sustancialmente relacionado con la dimensión moral de ésta, nuestra Constitución ha elevado también a valor jurídico fundamental la dignidad de la persona, que, sin perjuicio de los derechos que le son inherentes, se halla intimamente vinculada con el libre desarrollo de la personalidad (art. 10) y los derechos a la integridad física $y$ moral (art. 15), a la libertad de ideas y creencias (art. 16), al honor, a la intimidad personal y familiar $y$ a la propia imagen (art. 18.1). Del sentido de estos preceptos puede deducirse que la dignidad es un valor espiritual $y$ moral inherente a la persona, que se manifiesta singularmente en la autodeterminación consciente y responsable de la propia vida y que lleva consigo la pretensión al respeto por parte de los demás».

En este sentido, en relación con la eficacia jurídica de este principio, el Tribunal apreció, en la STC 120/1990, de 27 de junio, que

"Proyectada sobre los derechos individuales, la regla del art. $10.1 \mathrm{CE}$ implica que, en cuanto valor espiritual y moral inherente a la persona, la dignidad ha de permanecer inalterada cualquiera que sea la situación en que la persona se encuentre, constituyendo, en consecuencia, un "minimum" invulnerable que todo estatuto juridico debe asegurar, de modo que, sean unas $u$ otras las limitaciones que se impongan en el disfrute de los derechos individuales, no conlleven menosprecio para la estima que, en cuanto ser humano, merece la persona».

Asimismo, y por esta centralidad de la dignidad humana, este estatuto jurídico, mínimum invulnerable, no puede verse afectado por la cláusula de Estado autonómico, de manera que quedan vedadas las discriminaciones en el disfrute de los derechos fundamentales por razón del territorio en que viva una persona, derechos fundamentales que, en consecuencia, "forman parte del ordenamiento objetivo de una comunidad nacional" ${ }^{65}$.

Ahora bien, junto a esta interpretación cabe otro entendimiento de la relación entre democracia pluralista y dignidad de la persona.

De nuevo en esta ocasión, para ilustrar nuestro razonamiento, acudiremos a la comparación de nuestra Norma constitucional con la Ley Fundamental de Bonn, ya que a nuestro juicio hay diferencias importantes en lo que respecta a la consagración de la dignidad de la persona como valor fundamental en ambos ordenamientos.

${ }^{65}$ STC 25/1981, de 14 de julio. 
Esta diferencia se aprecia ya en el mismo Preámbulo de la Ley Fundamental, pues aun cuando dicha Ley tiene su origen en un acto deli poder constituyente del pueblo alemán, éste ejerce dicho acto "consciente. de su responsabilidad ante Dios y los hombres».

Cuando, en el art. 1, se proclame la dignidad de la persona, esta expresión del Preámbulo adquirirá una especial significación, pues implica। el reconocimiento de que la dignidad y los derechos a ella inherentes son anteriores a su reconocimiento por el Estado ${ }^{66}$, y por tanto, que no son dis-. ponibles ni por el propio poder constituyente.

Además cobra sentido la dicción del propio art. $1 \mathrm{LF}$, con arreglo al cual

1. La dignidad del hombre es intangible. Respetarla y protegerla es obligación de todo poder público.

2. El pueblo alemán se identifica con los inviolables e inalienables derechos del hombre como fundamento de toda comunidad humana, de la paz y la justicia en el mundo.

3. Los derechos fundamentales vinculan a los poderes legislativo, ejecutivo y judicial a título de derecho directamente aplicable».

Si comparamos la literalidad del artículo, especialmente en su apartado $1^{\circ}$, y la comparamos con la del apartado 1 del art. 10 CE ( «La dignidad. de la persona, los derechos inviolables que le son inherentes, el libre desarrollo de la personalidad, el respeto a la ley y a los derechos de los demás son fundamento del orden político y de la paz social»l, además de evidentes semejanzas encontramos significativas diferencias. Así, en nuestro: texto constitucional, por un lado, la dignidad deja de ser intangible, o lo; que es lo mismo, indisponible para cualquier actuación del poder, aunque: sea el constituyente, indisponibilidad que se proyecta, a nuestro entender, en la cláusula de intangibilidad del art. 79.3 LF; y, por otro, y en consecuencia, los derechos pierden el calificativo de inalienables.

Diferencias en los artículos que no traen causa, a nuestro entender, más que de la ausencia de un fundamento metafísico - teísta o no- de la: dignidad de la persona ${ }^{67}$, la cual en nuestro ordenamiento constitucionali

${ }^{66}$ Cfr. I. von MüNCH. La dignidad del hombre en el Derecho Constitucional. Revista Española de Derecho Constitucional, núm. 5. 1982, p. 26.

${ }^{67}$ En sentido contrario se inclina Garrido Falla en su Comentario al art. 10, en los Comentarios a la Constitución por él dirigidos. Civitas, Madrid, 1985. Así, literalmente afirma que "nuestra Constitución se adhiere a una metafísica personalista (naturae rationalis individua substantia, como definiera Boecio)". 
no tiene más fundamento que la voluntad de la Nación española, sin referencia alguna a un orden trascendente ${ }^{68}$.

Además, la condensación de los tres apartados del art. 1 LF en un único apartado del art. $10 \mathrm{CE}$ tiene otra consecuencia: la dignidad de la persona queda al nivel del libre desarrollo de la personalidad, libre desarrollo de la personalidad que debe ser entendido en el sentido de la completa autonomia personal en virtud del pluralismo sin limites que contempla la Constitución.

De esta devaluación del valor de la dignidad de la persona se desprende que la norma fundamental de nuestro texto constitucional debe entenderse, en nuestra opinión, que es la que deriva del principio democrático y de la proclamación de la soberanía popular, de tal manera que es la aplicación de ese principio democrático el apoyo último de legitimidad de todo el Derecho ${ }^{69}$, pues, como ha señalado el Tribunal Constitucional, dicho principio de legitimidad democrática es la "base de toda nuestra ordenación jurídico política» ${ }^{70}$. Es decir, que en nuestra ordenación jurídico-política el Derecho creado por un acto del poder sólo recibe su justificación del mencionado principio democrático.

Esta primacía del elemento democrático en nuestro texto constitucional puede desprenderse asimismo, a nuestro juicio, de la STC 108/1986, de 29 de julio. En esta Sentencia, que resuelve el recurso de inconstitucionalidad presentado contra la Ley Orgánica 6/1985, de 1 de julio, del Poder Judicial (en adelante, LOPJ), el Tribunal hace una serie de reflexiones que son importantes en relación con el asunto que venimos tratando.

Así, por ejemplo, en relación con la competencia de las Cortes Generales y la extensión de sus funciones. Para los recurrentes, cuando el apartado 2 del art. 66 CE señala que "las Cortes Generales ejercen la potestad legislativa del Estado, aprueban sus presupuestos, controlan la acción del Gobierno y tienen las demás competencias que les atribuya la Constitución", lo que está haciendo el texto constitucional (sobre la base de la división de poderes, por lo que habría que interpretar este art. 66.2 en relación con los artículos 97 y $117 \mathrm{CE}$ ) es señalar que las Cortes Generales sólo pueden ejercer esas funciones tasadas en el apartado citado más aquellas que estén expresamente atribuidas en la Constitución. Argumento con base en el cual ponían de manifiesto los recurrentes cómo el cambio en la

68 Cfr. L. SÁnChez Agesta. Sistema político de la Constitución Española de 1978, p. 75.

69 Cfr. A. Garrorena Morales. Voz Estado democrático, Temas básicos de Derecho Constitucional, p. 110 y ss.

70 STC 6/1981. 
forma de designación de los Vocales del Consejo General del Poder Judicial (al disponer la LOPJ de 1985 que los doce Vocales que deben designarse entre Jueces y Magistrados también sean elegidos por las Cortes, frente al sistema de la Ley de 1980) no sólo alteraba el equilibrio de poderes y abría la puerta a la politización de la Justicia, sino que implicaba una extensión de las Cortes Generales a funciones que no le asignaba la Constitución, convirtiéndose el Legislativo en una suerte de Constituyente.

Pues bien, a este respecto, el Tribunal Constitucional, en la Sentencia que estamos comentando, afirmó que la recta interpretación del último inciso del art. 66.2 de la Norma suprema no es que las Cortes sólo puedan tener las funciones expresamente contenidas en la Constitución, sino que ésta les asigna algunas que forzosamente han de cumplir y que la ley no puede atribuir a ningún otro órgano, sin que ello suponga que, por ley, no pueda reconocérseles otras, que no estén específicamente mencionadas en la Constitución, conclusión a la que llega por la naturaleza de las Cortes en un régimen parlamentario como es el español (art. 1.3 CE) y por la relevancia jurídico-constitucional del elemento democrático y representativo que constituyen las Cámaras.

De esta forma, a nuestro entender, lo que está afirmando el Tribunal es precisamente esa primacía de la democracia que conlleva que, democráticamente, las Cámaras puedan legislar sobre todas las materias que puedan darse en la vida social, así como que gozan de un principio legitimador para intervenir $-y$ no sólo ejerciendo la potestad legislativa del Estado, que es lo que señala el art. 66.2 CE - en todos los sectores de la vida de la comunidad nacional. Además, y dado que no hay límite alguno al pluralismo en nuestro texto constitucional, podrán decidir prácticamente cualquier cosa, con los únicos límites formales o competenciales que establece la propia Constitución. Eso si, en algunos asuntos se necesitará una mayoría cualificada para la regulación (legislación orgánica), mayoría cualificada que expresa la necesidad de que en temas que se consideran especialmente importantes por la propia norma fundamental deba acudirse a la democracia de consenso.

Queda fuera de estas líneas un estudio de la reserva de Ley Orgánica en nuestro ordenamiento juridico-constitucional, pero de nuevo hemos de hacer algunas reflexiones sobre dicha reserva al hilo de lo que venimos comentando, sobre todo en relación con esa suerte de "devaluación» de la dignidad de la persona que consideramos presente en la Constitución.

Ya tempranamente dijo el Tribunal Constitucional que las reservas de Ley Orgánica son únicamente aquéllas expresamente establecidas por la Constitución en el art. 81 y conexos, y que tales reservas resultan de carácter material y no formal. Precisamente por este carácter material de la reserva de 
Ley Orgánica, aquéllas materias ajenas al derecho fundamental que se regula en una Ley Orgánica no gozan definitivamente de la fuerza pasiva inherente a dicha clase de leyes aunque se incluyan en ellas ${ }^{71}$, conclusión a la que llega el Tribunal con objeto de evitar «una petrificación abusiva en beneficio de quienes en un momento dado gozasen de la mayoría parlamentaria suficiente y en detrimento del carácter democrático del Estado, ya que nuestra Constitución ha instaurado una democracia basada en el juego de las mayorías, previniendo tan sólo para supuestos tasados y excepcionales una democracia de acuerdo basada en mayorías cualificadas o reforzadas» ${ }^{72}$.

Pues bien, dentro de estos supuestos tasados y excepcionales en que es necesaria una democracia de consenso, no incluye el Tribunal a la dignidad de la persona ${ }^{73}$. En nuestra opinión, tiene razón el Magistrado don Manuel Jiménez de Parga en su Voto particular en la STC 116/1999 (al que se adhiere don Fernando Garrido Falla), cuando destaca el sinsentido que supone que la Ley Orgánica sea necesaria para desarrollar los derechos fundamentales y no lo que, materialmente, es el tronco del gran árbol (la dignidad de la persona). Pero en todo caso el hecho es que la interpretación que se impone, que es la realizada por el Tribunal Constitucional, ha confirmado esta menor consideración de la dignidad de la persona en nuestro ordenamiento constitucional.

En relación con la protección de la dignidad de la persona en la Ley Fundamental, considera Maihofer que "en un Estado secular y plural como el nuestro, este carácter deliberadamente abierto del significado de la expresión dignidad humana no cabe convertirlo en definitivamente unívo$\cos ^{74}$. Y si esto se puede decir de la Ley Fundamental, ¿a qué conclusiones no se podrá llegar en nuestra regulación constitucional?

De esta manera, si no podemos afirmar un significado univoco para la expresión dignidad humana, por mucho que quede garantizada en el orden constitucional, no parece que sea más que un significante sin un significado preciso, significado que entonces dependerá del momento y la interpretación. Significante sin significado unívoco, o lo que es lo mismo, la vuelta de la supremacía constitucional al orden formal.

71 Cfr. SSTC 5/1981, 224/1993, 123/1994.

72 STC 5/1981.

73 Cfr. SSTC 212/1996, de 19 de diciembre, y 116/1999.

74 W. MalHofer. Principios de una democracia en libertad, Manual de Derecho Constitucional, p. 79. Ahora bien, como señala Pedro Serna, "lo único que puede decirnos un consenso puramente fáctico es que la dignidad humana es ahora valiosa, pero mañana puede no serlo» (Cfr. Positivismo conceptual y fundamentación de los derechos humanos, p. 147). 
Conclusión a la que llega Loewenstein, quien en su Teoría de la Constitución ${ }^{75}$ considera que el creciente pluralismo de la sociedad lleva a la erosión implacable y la destrucción final de la libertad y la autodeterminación individual, para llegar, en último término, a la anarquía. $Y$ como la única alternativa al gobierno privado es el gobierno público, esto es, el gobierno por el Estado, será éste el encargado de crear el orden. Lo que lleva a este autor a cerrar el libro, precisamente, con un epígrafe que dice $Y$ de nuevo las sombras de Leviatán.

Cuestión distinta es que la evolución de las sociedades pluralistas, después del Leviatán ${ }^{76}$, haya discurrido por el camino del individualismo sin límites en que cualquier pretensión subjetiva puede ser elevada a derecho. Así, no debe extrañarnos que la dignidad humana y el libre desarrollo de la personalidad, desprovistos de fundamento metafísico en nuestra sociedad plural, sea sinónimo de completo individualismo, individualismo que, con la retórica de la ausencia de daños a terceros, se proyecta sobre los derechos fundamentales ${ }^{77}$. De tal manera que incluso se pueda sostener que no hay un concepto constitucional de matrimonio ${ }^{78}$, y en consecuencia quepa el matrimonio entre homosexuales, pues aun cuando no es un derecho constitucionalmente garantizado (ATC 222/1994), lo constitucionalmente garantizado no agota lo constitucionalmente admisible, que en virtud del pluralismo sin límites es prácticamente todo. Cualquier pretensión subjetiva, por tanto, es constitucionalmente admisible, y su incorporación como derecho al ordenamiento dependerá, simplemente, de la capacidad de presión que los afectados tengan sobre el legislador.

Esto tiene su proyección en relación con los derechos fundamentales, precisamente por ser éstos la expresión jurídica de un sistema de valores. Así, el pluralismo postmoderno hace que la concepción de los derechos esté tan orientada al individuo que ignora las dimensiones de la sociedad civil, lo cual implica una supremacía del individuo aislado sobre 466 a 468 .

75 K. Loewenstein. Teoría de la Constitución, Ariel, $2^{a}$ edición, Barcelona, 1976, p.

${ }^{76}$ Cfr. M. Ayuso Torres. ¿Después del Leviatán? Sobre el Estado y su signo. Dykinson, $2^{\text {a }}$ edición, Madrid, 1998.

77 Decimos retórica de la ausencia de daños a terceros porque al no admitirse los daños que la destrucción del ambiente moral pueda causar a esos terceros, toda regulación debe ser admitida. Y es que, dado que nadie está obligado a divorciarse, a abortar, etc., las leyes permisivas de estas conductas no perjudican a nadie... salvo a aquellos que ya no pueden contraer matrimonio indisoluble o vivir protegidos por un ordenamiento que ampara a la persona no nacida.

78 J. V. GAVIDIA SÁNCHEZ. Uniones homosexuales y concepto constitucional de matrimonio. REDC núm. 61, enero-abril de 2001, p. 43 y ss. 
cualquier dimensión social que pudiera considerarse, $y$ en estas circunstancias es el propio constitucionalismo el que ha cambiado ${ }^{79}$.

Dentro de esa posibilidad ilimitada del sistema relativista de derechos, destaca la mentalidad para la que toda norma no consentida es una imposición, con la consiguiente eclosión de cláusulas de conciencia (precisamente como cautela a ese regreso del Leviatán de que hablaba Loewenstein). A esta consecuencia de la erosión que para la obediencia al Derecho implica la afirmación del pluralismo sin límites dedicaremos el siguiente epigrafe.

\section{b) La cuestión de las objeciones de conciencia}

Normalmente se señala que una de las consecuencias de la positivación de valores en la Constitución es la de dar una mayor legitimidad al ordenamiento. Así, en la medida en que el ordenamiento reconoce unos valores superiores que debe propugnar (art. 1.1 CE), el ordenamiento se hace especialmente valioso. Esta legitimación axiológica del ordenamiento se proyecta, además, en la cuestión de la obediencia al Derecho, obediencia que -en el esquema que estamos presentandono será simplemente por miedo a la sanción (esto es, la coacción como nota esencial de lo jurídico), sino precisamente por el reconocimiento de los valores que las normas tratan de realizar. No sólo por ser normas emanadas de un poder democrático (por considerar que los ciudadanos en el fondo no hacen más que obedecerse a sí mismos), sino por el contenido material valorativo que subyace al ordenamiento constitucional del Estado constituido en 1978.

Pues bien, la consagración constitucional del pluralismo, en los términos que se han puesto de manifiesto, a nuestro entender, afectan también a esta función del orden axiológico constitucional que es fundamentar la obediencia al Derecho.

79 Cfr. A. J. Gómez Montoro. Comentario al artículo de Daniel Elazar, Changing conceptions of rights in the United States and the West, Publius: The Journal of Federalism, en REDC núm. 36, 1992. Resalta Gómez Montoro cómo "originariamente, las constituciones, aunque podían ser interpretadas con gran flexibilidad, suponían un veto a determinadas acciones (que eran inconstitucionales). Bajo las condiciones de relativismo de la comprensión postmoderna de los derechos, lo máximo que la Constitución puede suponer es un voto. Para el autor, esto elimina el propósito último del constitucionalismo y abre posibilidades ilimitadas para un sistema relativista de derechos $y$ acciones». 
En efecto, si debemos entender el pluralismo como legitimidad para adoptar cualquier representación del hombre y del mundo que uno quiera, precisamente por la ausencia de fundamento real del resto de valores (por tanto, también de la dignidad de la persona), y en virtud del derecho al libre desarrollo de la personalidad (entendido también en sentido pluralista como derecho a concebir - y no ser molestado en la realización prácticala propia vida como uno estime conveniente, a partir de una autodeterminación personal sin límites), quiebra la razón de obediencia a las normas.

Con estos presupuestos, que a nuestro entender son los que se derivan de la configuración constitucional del pluralismo y su proyección en el resto del orden jurídico-político (dignidad de la persona, libre desarrollo de la personalidad, etc.), al menos tal y como lo ha interpretado el Tribunal Constitucional, se hace imposible encontrar un fundamento distinto de la coacción para la obediencia al Derecho. Es más, en la medida en que en virtud de este pluralismo axiológico ningún comportamiento puede ser considerado normal ${ }^{80}$, no queda más criterio que el de la mayoría para definir lo justo y lo injusto, y cualquier norma no compartida por el individuo sería en realidad violencia contra el disidente ${ }^{81}$.

Desde estos presupuestos, cobra especial relevancia la objeción de conciencia, para evitar que la imposición de la norma vulnere el derecho al libre desarrollo de la personalidad (unido a la libertad ideológica).

ElTribunal Constitucional ha señalado que el derecho a la objeción de conciencia es una manifestación o especificación de la libertad de conciencia y, dado que ésta es una concreción de la libertad ideológica reconocida en el art. 16 de la C. E., puede afirmarse que la objeción de conciencia es un derecho reconocido explícita e implícitamente en el ordenamiento constitucional españo| ${ }^{82}$, habiéndolo reconocido el Tribunal en un ámbito diferente del de la oposición a prestar servicio de armas para colaborar en la defensa nacional. Así, por ejemplo, en la Sentencia 53/1985, dictada con motivo del recurso de inconstitucionalidad promovido contra la despenalización del aborto, el Tribunal señaló que

"Por lo que se refiere al derecho a la objeción de conciencia, que existe y puede ser ejercido con independencia de que se haya dictado o no

${ }^{80}$ Cfr. E. Gallego. Norma, normativismo y Derecho, Dykinson, Madrid, 1999. En esta obra, Gallego pone de manifiesto la relación entre conducta normal (adecuada a la naturaleza racional del hombre) y norma jurídica.

$81 \mathrm{Cfr}$. D. CAstellano. El derecho natural, fundamento ético de la política. Actas de las II Jornadas Hispánicas de Derecho Natural. Publicaciones CajaSur, Córdoba, 2001, p. 159 y ss.

82 STC 15/1982, de 23 de abril. 
tal regulación. La objeción de conciencia forma parte del contenido del derecho fundamental a la libertad ideológica y religiosa reconocido en el artículo 16.1 de la Constitución y, como ha indicado este Tribunal en diversas ocasiones, la Constitución es directamente aplicable, especialmente en materia de derechos fundamentales».

En consecuencia, parece que el Tribunal Constitucional reconoce un genérico derecho a la objeción de conciencia, que permitiría incumplir una norma cuando su contenido sea contrario a lo que dicte la conciencia subjetiva del individuo. Doctrina ésta que, llevada a sus últimas consecuencias, hace imposible la vida comunitaria, pues al impedir el pluralismo axiológico y la absolutización de la conciencia subjetiva formar una voluntad conjunta de la pluralidad de voluntades existentes en la sociedad, quiebra el Estado como unidad política de acción.

Es cierto que en varias ocasiones ha declarado el Tribunal Constitucional que el derecho a la libertad ideológica reconocido en el art. 16 C.E. no resulta suficiente para eximir a los ciudadanos por motivos de conciencia del cumplimiento de deberes legalmente establecidos, con el riesgo aparejado de relativizar los mandatos legales ${ }^{83}$. También ha señalado el Tribunal que el pluralismo opera dentro del marco constitucional y de la debida obediencia a sus normas ${ }^{84}$, asi como que si se puede afirmar que el derecho a la objeción de conciencia es un derecho autónomo, no es un derecho fundamental (Sentencias 160 y 161 de 1987).

Ahora bien, consideramos con Ayuso ${ }^{85}$ que esto es más bien una postura inconsecuente con los propios postulados ideológicos del constitucionalismo para evitar las consecuencias que para la vida comunitaria tiene la aplicación hasta sus últimas consecuencias del citado derecho a la objeción de conciencia. Inconsecuencia con los postulados ideológicos del constitucionalismo que acreditan, en nuestra opinión, los votos particulares formulados en las Sentencias 160 y 161 de $1987^{86}$.

${ }^{83}$ SSTC 101/1983, 160/1987, 127/1988.

84 STC 122/1983, de 16 de diciembre.

85 Cfr. El ágora y la pirámide. Una visión problemática de la Constitución Española, p. 144.

${ }^{86}$ En su voto particular a la STC 160/1987, de 27 de octubre, el Magistrado don Carlos de la Vega señaló que la libertad de conciencia, la cual supone no sólo el derecho a formar libremente la propia conciencia sino también a obrar de modo conforme a los imperativos de la misma". De ahi que, como "la libertad de conciencia es una concreción de la libertad ideológica" - en términos de la misma Sentencia- pueda considerarse ahora yendo más allá, que la objeción de conciencia sea un derecho reconocido en el ordenamiento constitucional, y consiguientemente como derecho fundamental por su 
De hecho, en una reciente Sentencia, el Tribunal Constitucional ha llegado a eximir del cumplimiento de una norma por razones de conciencia ${ }^{87}$.

$Y$ es que de nuevo nos encontramos con una de las aporías del constitucionalismo contemporáneo y la ideología de la democracia pluralista.

A nuestro entender, un ejemplo de esta aporía lo podemos encontrar en el apartado 2 del art. 3 de la Ley de Extranjeria ${ }^{88}$, que dispone lo siguiente

"Las normas relativas a los derechos fundamentales de los extranjeros se interpretarán de conformidad con la Declaración Universal de Derechos Humanos y con los Tratados y Acuerdos internacionales sobre las mismas materias vigentes en España, sin que pueda alegarse la profesión de creencias religiosas o convicciones ideológicas o culturales de signo diverso para justificar la realización de actos o conductas contrarios a las mismas".

Decimos aporía porque, precisamente, los textos que cita este precepto consagran el derecho a actuar según la propia conciencia subjetiva, pues uno de los derechos fundamentales de las normas internacionales de derechos humanos como es el de la libertad ideológica y religiosa implica el poder ajustar el comportamiento propio a lo que se desprenda del claustro íntimo de convicciones que, en ejercicio de la autodeterminación indivi-

intrínseco contenido. Por su parte, en su voto particular a la STC 161/1987, de 27 de octubre, el Magistrado don Ángel Latorre señaló que "la libertad ideológica es el fundamento de la objeción de conciencia $y$, en último término, el bien constitucional que en una manifestación concreta protege el citadọ art. 30.2n.

87 STC 154/2002, de 18 de julio. Aun cuando en su razonamiento el Tribunal no lo. señale expresamente. En el caso de un menor de edad perteneciente a los Testigos de. Jehová muerto por no haber recibido transfusiones de sangre. Los padres del menor fueron condenados por haber incumplido los deberes que les impone el ordenamiento en cuanto garantes de su hijo. EITC otorga el amparo por considerar que, dado que no habian mostrado oposición o ánimo de contravenir las decisiones de los poderes públicos o del Juez, y la actuación de éstos podría haber evitado la muerte del menor, no, podia exigírseles - pese a su condición de garantes - una actuación positiva contraria a sus convicciones. A pesar de este argumento, a nuestro juicio lo que hace el Tribunall es excluir la aplicación de una norma por dictar un comportamiento contrario a la conciencia subjetiva de los recurrentes. No es válido, a nuestro entender, lo que señala eli Tribunal al decir que el Juez podría haber ordenado la transfusión, y que como losi padres no mostraron intención de hacer de imposible cumplimiento una orden en este sentido, se podría haber tutelado la vida del menor de una manera que no implicara limitación del derecho a la libertad ideológica y religiosa de los padres, pues de no haber alegado estos un motivo religioso (que en nuestro ordenamiento es un motivo perteneciente a la conciencia privada subjetiva de cada cual, Cfr. STC 177/1996) sí hubieran quedado vinculados por su condición de garantes y su inactividad habría determinado su condena en el delito de omisión que confirmó el Tribunal Supremo.

88 Ley orgánica $4 / 2000$, de 11 de enero, modificada por la Ley orgánica $8 / 2000$, de 22 de diciembre. 
dual, adopta cada sujeto como representación del mundo y la vida.Y la limitación de este agere licere, a nuestro entender, no puede venir más que por la afirmación de que el pluralismo se circunscribe al método para designar a los representantes de los ciudadanos y a los titulares del poder público, y que dicho valor está subordinado a otros de contenido material con fundamento real (metafísico), más allá de la neutralidad del Estado. Pero esto, obviamente, no parece ser lo que se desprende de nuestro orden constitucional, tal y como ha sido interpretado por el Tribunal Constitucional.

En efecto, en nuestro ordenamiento jurídico-constitucional encontramos, por un lado, el pluralismo como valor principal, que opera como criterio rector de la determinación del sentido y contenido del resto de valores (por la tantas veces repetida ausencia de fundamento real -metafísico- de los valores jurídicos), lo que nos devuelve la Constitución a una concepción formal (al menos en los asuntos en que el consenso social es inexistente en nuestras sociedades: aborto, experimentación con embriones, matrimonio y familia, eutanasia, etc.). Por otro, $y$ ante el temor que produce una concepción exclusivamente formal del Derecho en que la obediencia a la norma por la coacción lleve al imperio de la razón de Estado sobre la persona, se eleva la conciencia subjetiva a criterio de moralidad $y$, como consecuencia, de legitimidad del derecho y razón de la obediencia, con el debilitamiento de la pretensión de validez del ordenamiento estatal, conclusión que podemos sacar de la citada STC 154/2002.

Así pues, la aporía que señalamos encuentra difícil solución desde los planteamientos $y$ presupuestos propios del pluralismo, pues precisamente la admisión de ese pluralismo (vinculado a la libertad ideológica y religiosa) determina que no nos encontremos ante una objeción de la conciencia sino ante un pretendido derecho a la objeción de conciencia.

Uno de los mayores estudiosos en el panorama jurídico español de la cuestión de la objeción de conciencia, Navarro Valls, ha puesto esto de manifiesto ${ }^{89}$. Asi, destaca cómo "el objetor, a veces, de custodio de la verdad (en sus sentido atemporal y objetivo) pasa a creador de una verdad futura, histórica y subjetiva", precisamente por la secularización tanto de la propia objeción de conciencia como de las sociedades occidentales y de los fundamentos de su organización jurídico-política ${ }^{90}$, pasando a ser «no

89 Cfr. R. Navarro Valls. Las objeciones de conciencia. En el volumen Estudios de Derecho Constitucional. Homenaje al Prof. Rodrigo Fernández Carvajal. Universidad de Murcia, 1997.

90 Proceso secularizador que se encuentra en el origen del principio de neutralidad estatal y en el nacimiento del moderno Estado de Derecho. 
tanto una reivindicación del derecho contra la ley cuanto una reivindicación de la praxis contra el derecho" ${ }^{91}$.

Con objeto de salvar este inconveniente - pues con el derecho a la objeción de conciencia se elevaría a derecho cualquier pretensión de una conciencia subjetiva - a juicio de Navarro Valls este derecho debe ser reconocido pero dejando al Juez capacidad para delimitar, jurisprudencialmente, las condiciones de su ejercicio, por medio de una recuperación de la condición prudencial de la razón jurídica como especie de la razón práctica. En todo caso, y para poner coto al subjetivismo e individualismo a que puede dar lugar un reconocimiento del derecho a la objeción de conciencia, estima que tienen que tener protección preferente las objeciones de conciencia que tengan un origen religioso antes que las ideológicas, y las. que derivan de la conciencia de un grupo social que la subjetivas individuales; razonamiento éste que nos parece al menos cuestionable en relación con el principio de la neutralidad estatal, pues, ¿en virtud de qué razón debe primar lo religioso sobre lo ideológico? ¿cómo saber si un determinado "claustro íntimo de creencias" es una manifestación del fenómeno. religioso o ideológico, si el criterio es la "autodeterminación personal». (STC 177/1996)? ¿qué argumento - más allá de su indudable efecto práctico limitador de la atomización social- determina que tenga una protección, preferente la objeción de conciencia que deriva de la conciencia de un grupo social antes que las subjetivas individuales? Porque si bien es cierto que el argumento práctico tendente a limitar la atomización de la vida: social y política tiene bastante consistencia, no es menos cierto, a nuestro: juicio, que traslada la cuestión del ámbito de protección de la conciencia (custodia de la verdad) al ámbito del número y la capacidad de hacer valer los argumentos propios en el debate público, esto es, a la fuerza.

De nuevo se nos presenta como insalvable esta aporía, al menos: desde los presupuestos del constitucionalismo pluralista.

\section{CONCLUSIONES}

El problema que nos plantea el pluralismo político entendido como: lo ha hecho, a nuestro juicio, el Tribunal Constitucional, es que nos lleva a una aporía en el orden dogmático constitucional y en la interpretación del ordenamiento.

91 R. Navarro Valls y J. Martinez Torrón, Las objeciones de conciencia en el derecho español y comparado, Ed. Mc Graw Hill, Madrid, 1997, p. 6 y 7. 
En efecto, si el pluralismo es consecuencia de la falta de fundamento real de los valores constitucionales $-y$, muy especialmente, de la dignidad de la persona, que no puede ser considerada de manera objetiva en una sociedad secularizada y plural - , y por tanto se convierte en un método de naturaleza formal para integrar en la voluntad estatal (expresada en forma de normas jurídicas) las distintas concepciones del hombre y de sus exigencias en la vida social presentes en la sociedad en cada momento, el orden jurídico vuelve al campo del formalismo, a pesar de la enunciada dimensión del orden constitucional como un orden material de valores.

En esta interpretación de la norma constitucional "liberada" de toda metafísica, lo esencial es la actualización y concreción del consenso fundamental adoptado en el momento constituyente; consenso que -en aquellos campos en que la fragmentación ideológica de la sociedad es mayor- es más sobre los significantes que sobre los significados ${ }^{92}$.

Cierto es que, en esta labor de actualización del consenso el legislador cuenta con un límite: lo señalado en la propia Constitución. Ahora bien, a nuestro entender este límite no permite dar una respuesta satisfactoria a la aporía.

El propio pluralismo, valor constitucional superior (ex art. 1.1), determina que esta labor del Tribunal Constitucional, que en definitiva implica que corresponde al Tribunal fijar los parámetros morales básicos de la sociedad, no pueda hacerse por criterios estrictamente jurídicos, al menos en los supuestos límite, como se puede observar en el caso de las Sentencias del Tribunal español en el caso del aborto, la esterilización de disminuidos psíquicos, las técnicas de reproducción asistida, etc. En estas Sentencias, el Tribunal razona a partir de premisas morales o ideológicas, para las cuales los valores (sobre todo la dignidad de la persona) carecen de consistencia jurídica real.

Es claro que en aquellos asuntos en que el consenso no es cuestionado, como por ejemplo en los principios que se deducen de la cláusula del Estado de derecho, o las garantías procesales del art. 24, la argumentación del Tribunal si pueda descansar sobre conceptos jurídicos aquilatados por la experiencia y la tradición de nuestro entorno jurídico. Pero esto

92 Un ejemplo paradigmático es el art. 27 y la regulación constitucional de los derechos educativos. A propósito de las fórmulas de consenso en el texto constitucional, Sánchez Agesta incluye la ambigüedad, esto es, el acuerdo sobre el significante sin atribuir al mismo un significado unívoco. Lo cual afecta - como se verá más adelanteal tema que estamos estudiando. Cfr. Luis SÁnCHEZ AGESTA. Sistema político de la Constitución Española de 1978, p. 95 y ss. 
no impide que, en aquellos asuntos en los que está en juego la imagen del hombre y la afirmación de la dignidad humana frente al poder público o privado, la elevación del pluralismo a valor constitucional superador de la falta de fundamento del resto de valores reconvierta la Constitución en un mero orden formal, bajo cuya pretensión de validez y supremacía late la ilimitación del poder. Una así entendida interpretación del pluralismo, a nuestro juicio, socava los propios cimientos del Estado constitucional.

$Y$ es que cuando no es posible ligar el deseo y búsqueda de felicidad a la naturaleza humana, nada es normal, o todo es normal -que eso es lo que esconde la neutralidad ideológica del Estado- y en consecuencia resulta imposible determinar una diferencia real, sustancial y no sólo formal entre derecho $y$ abuso.

De esta forma, el derecho tiene que ser definido por el poder democrático, que ante la ausencia de un fundamento real, definirá el derecho, lo justo, según diga en cada momento quien consiga imponerse con el apoyo de la mayoría.

Así, la convivencia democrática esconde una guerra de todos contra todos, donde corresponde al propio Estado, en virtud del pluralismo democrático, elevar el conflicto a principio rector de la vida política. Conflicto, competición respetando las reglas del juego democrático, en definitiva, construcción del orden social a partir de la fuerza, como puso de manifiesto Peces Barba en el propio debate constitucional ${ }^{93}$.

Corresponde al poder que crea el derecho y define lo justo, eso sí, democráticamente, convertirse en un elemento constitutivo de la moral, por la función pedagógica que toda norma -incluso aquella que se niega a sí misma al señalar que todo comportamiento es normal- por su propia naturaleza tiene. Esta definición de lo moral por parte del poder -con su traducción en la consideración que tiene la persona en nuestro ordenamiento - mina las bases sociales sobre las que se asienta el Estado constitucional, que vive de presupuestos que él no puede crear pero si, en todo caso, destruir.

${ }^{93}$ El Prof. Peces-Barba dijo, a propósito del debate sobre el aborto en relación con el art. 15 CE: "Desengáñense Sus Señorías, todos saben que el problema del Derecho es el problema de la fuerza que está detrás del poder político y de la interpretación. Y si hay un Tribunal Constitucional y una mayoría proabortista, "todos" permite una ley de aborto; $y$ si hay un Tribunal Constitucional y una mayoría antiabortista, "la persona» impide una ley de aborto". Cita tomada del libro del propio Peces-Barba La Constitución Española de 1978. Un estudio de Derecho y Política, Fernando Torres Editor, Valencia, 1981, p. 302. 
Cuestión distinta es que los titulares del poder aspiren realmente a la aplicación de las normas que dictan. Debates públicos como los acaecidos con ocasión del procedimiento para instar la ilegalización de Batasuna en aplicación de la Ley de Partidos, nos permiten cuando menos suponer que hay normas que no nacen para ser aplicadas. "Esta norma - hemos podido leer a algún responsable político en relación con la Ley de Partidos - fue elaborada con la vocación de ser aplicadan. ¿Simple forma de hablar o desliz que expresa una forma de entender el derecho y la política? Una mirada a los anuncios en los periódicos de clínicas autorizadas para la interrupción voluntaria del embarazo (que en nuestro ordenamiento sigue siendo un delito del que se excluye la pena en determinados supuestos $\rangle$, o la situación en el sector de las telecomunicaciones y medios audiovisuales (con auténticas redes nacionales de televisiones locales, pese a lo que dispone la legislación al respecto) nos permite señalar que quizá, y no desvinculada de la pluralista ausencia de fin en la vida social, el ordenamiento jurídico ordene más virtual que realmente ${ }^{94}$.

Recordando a Bertrand de Jouvenel, Vallet de Goytisolo ${ }^{95}$ nos ha alertado sobre la ilusión, que desemboca en el absurdo, de pretender una sociedad donde todo sea justo (también la convivencia pacífica que señala el preámbulo constitucional) sin que nadie tenga que serlo. Absurdo que, a nuestro juicio y como hemos señalado en estas líneas, devuelve la Constitución al plano formal, con la devaluación que implica para la protección de los derechos fundamentales de la persona.

Es preciso, pues, buscar la solución en otro plano, recuperando la fundamentación metafísica del Derecho. Como señala González Pérez ${ }^{96}$, "el hombre únicamente recuperará la seguridad y la confianza cuando vuelva a tener conciencia de que su dignidad es intangible, no porque así lo haya decidido una Asamblea internacional, un Dictador o un Parlamento, sino porque así lo prescribe la Ley eterna».

Sin esta vuelta a la metafísica, también en el Derecho constitucional, no queda más que la desencantada afirmación de Saint-Exupéry:

¿Qué nos importan las doctrinas políticas que pretenden lograr la plenitud de los hombres si, en primer lugar, no conocemos qué tipo de hombre quieren formar?

$94 \mathrm{~F}$. GenTILE. El ordenamiento jurídico, entre la virtualidad y la realidad. Prudentia luris-Marcial Pons, Madrid, 2001.

95 J. B. VALLET DE Gortisolo. De la virtud de la justicia a lo justo jurídico. En torno al Derecho Natural, Organización Sala Editorial, Madrid, 1973.

96 J. GonZÁlez Pérez. La dignidad de la persona, Civitas, Madrid, 1986, p. 202 y 203. 